\title{
Original paper \\ Petrogenesis of Miocene subvolcanic rocks in the Western Outer Carpathians (southeastern Moravia, Czech Republic)
}

\author{
David BURIÁNEK ${ }^{1,2 *}$, Kamil KROPÁČ ${ }^{3}$ \\ ${ }^{1}$ Czech Geological Survey, Leitnerova 22, 65859 Brno, Czech Republic; david.burianek@geology.cz \\ ${ }^{2}$ Department of Geological Sciences, Faculty of Science, Masaryk University, Kotlářrká 2, 61137 Brno, Czech Republic \\ ${ }^{3}$ Department of Geology, Faculty of Science, Palacký University Olomouc, 17. listopadu 12, 77146 Olomouc, Czech Republic \\ * Corresponding author
}

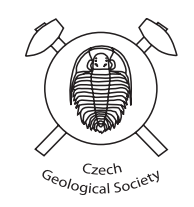

\begin{abstract}
Neogene subvolcanic rocks in southeastern Moravia form numerous dykes and laccoliths, ranging from clinopyroxene-amphibole and amphibole trachybasalt, through trachyandesite, to biotite-amphibole trachydacite. Leucocratic and melanocratic cumulate gabbro and basalt enclaves up to $70 \mathrm{~cm}$ in diameter are rarely present, respectively, within the trachydacite and trachyandesite.

The parental magmas rose along tensional fissures spatially related to the Nezdenice Fault but probably never reached the surface. The range of major (e.g., $\mathrm{SiO}_{2} 44-62 \mathrm{wt}$. \%, $\mathrm{mg \#} \mathrm{20-65)}$ and trace-element compositions can be explained through magma mixing and mingling and subsequent fractional crystallization.

Mineral chemistry shows limited compositional variation of mafic minerals. Diopside phenocrysts indicate narrow ranges of $\mathrm{X}_{\mathrm{Mg}}(0.65-0.84)$ and usually display normal zoning with small $\mathrm{Mg}$-rich cores and Fe-rich rims. Phlogopites from the trachydacite and gabbro enclaves show a mutually similar composition $\left(\mathrm{X}_{\mathrm{Fe}} 0.36-0.43\right.$ and $\left.{ }^{\mathrm{IV}} \mathrm{Al} 2.44-2.59\right)$. Amphiboles from individual samples of basalt, trachybasalt and trachyandesite are likewise chemically relatively homogeneous $\left(\mathrm{X}_{\mathrm{Mg}}\right.$ 0.51-0.86, Si 5.78-6.55). Chemical compositions of amphibole phenocrysts from the trachybasalts and trachyandesites indicate multi-stage crystallization at depth of 32 to $21 \mathrm{~km}$ for this magmatic system. Systematic changes in $\mathrm{Si}$, $\mathrm{Ti}$, ${ }^{\mathrm{VI}} \mathrm{Al}$, $\mathrm{X}_{\mathrm{Mg}}$ contents in amphiboles from trachydacites and gabbro enclaves can be explained by fractional crystallization in a shallower magma reservoir ( $20-10 \mathrm{~km})$.
\end{abstract}

Keywords: Neogene subvolcanic rocks, geochemistry, mineral chemistry, $P-T-X$ conditions, Western Outer Carpathians Received: 10 May 2018; accepted: 22 July 2019; handling editor: J. Hora

The online version of this article (doi: 10.3190/jgeosci.286) contains supplementary electronic material.

\section{Introduction}

Small laccoliths and dykes of high-K calc-alkaline subvolcanic rocks situated near Uherský Brod in southeastern Moravia (Czech Republic), together with occurrences in the Pieniny Mountains (southern Poland) and Nová Sedlica (northeastern Slovakia), represent the only three areas with Neogene magmatism in the Western Outer Carpathians (Nejbert et al. 2012; Kucharič et al. 2013). From the perspective of evolution of the Carpathian-Pannonian region, the subvolcanic rocks in the vicinity of Uherský Brod have a unique geological position (Harangi et al. 2007; Seghedi and Downes 2011) on the border between the Carpathians and the Bohemian Massif (Fig. 1). The emplacement of laccoliths and subvolcanic dykes post-dated thrusting and nappe formation in the Outer Carpathians (Přichystal 1993; Nejbert et al. 2012) following Middle Miocene collision of the Alcapa Block with southern margin of the European Platform (Anczkiewicz and Anczkiewicz 2016). The specific geochemical signatures of these subvolcanic rocks (e.g., enrichment in certain incompatible trace elements like $\mathrm{Nb}, \mathrm{Th}$, and LREE) are interpreted to be caused by the interaction between melts derived from the metasomatized upper lithospheric mantle and European Plate upper crustal material (Nejbert et al. 2012; Anczkiewicz and Anczkiewicz 2016).

Previous geological studies on Neogene magmatism in the Western Outer Carpathians (Přichystal 1993; Nejbert et al. 2012; Hrouda et al. 2015) have mainly focused on interpreting magmagenesis, determining the magmatic affinities of these rocks or interpreting emplacement to post-emplacement processes. In this study we combine new and previously published geochemical data to understand the magmatic evolution of ascending post-collisional magma at the margin of the European Plate. Furthermore, we used chemical composition of the rock-forming minerals (e.g., amphibole and plagioclase) to provide constraints on possible mechanisms of magma ascent, storage conditions and magmatic evolution of subvolcanic rocks that intruded into the sedimentary rocks of the Magura Nappe in the vicinity of Uherský Brod (Fig. 1). 


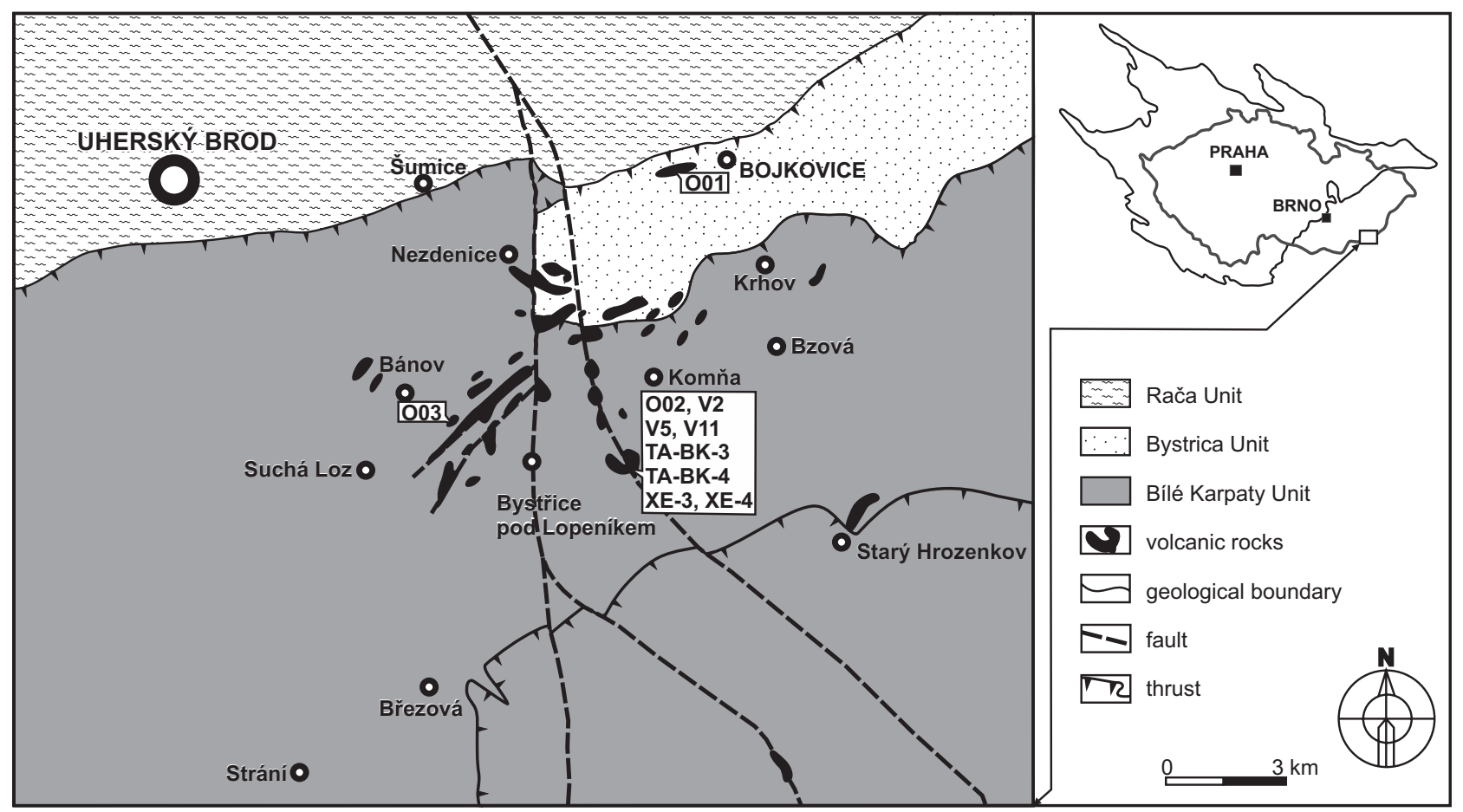

Fig. 1 Geological map of the studied area showing distribution of subvolcanic rocks and samples location (modified from Hrouda et al. 2015).

\section{Geological setting}

The Carpathian-Pannonian region was formed between the Late Jurassic and Neogene as a result of collision of two lithospheric blocks (Alcapa and Tisia) with the southern margin of the European Plate (Szabó et al. 1992; Kováč et al. 1998; Nemčok et al. 1998; Fodor et al. 1999; Jolivet et al. 1999; Tari et al. 1999; Harangi et al. 2001). Neogene to Quaternary tectonic processes were accompanied by calc-alkaline and alkaline magmatism irregularly distributed in the Carpathian-Pannonian region (Szabó et al. 1992; Harangi 2001; Harangi et al. 2001, 2007; Seghedi et al. 2005). Earliest calc-alkaline magmatism (between 20 and $10 \mathrm{Ma}$ ) in the Western Carpathians and Pannonian Basin (Pécskay et al. 1995; Konečný et al. 2002; Seghedi et al. 2004) had probably relationships with subduction rollback and back-arc extension (Lexa et al. 1995; Lexa and Konečný 1999) and/or delamination processes (Seghedi et al. 1998). The calc-alkaline magmas were generated above the subducting slab by melting of a heterogeneous asthenospheric mantle source modified by addition of fluids and sediments (Konečný et al. 2002; Seghedi et al. 2004). The next stage represented high-K calc-alkaline volcanic rocks, followed by alkaline volcanism that occurred under various local extensional conditions in the Carpatho-Pannonian region from the Late Miocene to the Quaternary (between 11 and $0.5 \mathrm{Ma}$; Pécskay et al. 1995; Seghedi et al. 2004).

The studied subvolcanic intrusive rocks (clinopyroxene-amphibole and amphibole trachybasalt to trachyandesite and biotite-amphibole trachydacite to trachyte) are located in southeastern Moravia in the surroundings of Uherský Brod, mainly in the area between the villages of Bánov, Suchá Loz, Komňa, Nezdenice, Bojkovice and Starý Hrozenkov (Fig. 1, Tab. 1). Southeastern Moravia hypabyssal post-tectonic intrusive complexes intruded part of the Carpathian accretionary prism (Přichystal 1998; Pécskay et al. 2006; Lexa et al. 2010). Numerous small dykes (e.g., Skalka Hill near Bánov) or small bodies (like trachyandesite to trachydacite cedar-tree laccolith on Bučník Hill near Komňa, Fig. 2a-d) intruded the flysch sediments of the Magura Nappe (Bílé Karpaty and Bystrica units). Dykes of volcanic rocks crosscut the thrust structures mostly without being affected by any subsequent tectonic movement (Hrouda et al. 2015), clearly documenting emplacement after the formation of the Magura Nappe (Přichystal 1993). The occurrences of subvolcanic rocks are bound to the Nezdenice Fault System (e.g., Hrouda et al. 2015). Their parental magmas rose along tensional fissures spatially related to the Nezdenice Fault, but probably never reached the surface. $\mathrm{K}-\mathrm{Ar}$ geochronological data indicate Middle Miocene age ( 14.7 to $11.0 \mathrm{Ma}$; Přichystal 1998; Pécskay et al. 2006, 2008). The country rocks are affected by contact metamorphism and subvolcanic rocks contain medium- to fine-grained mafic enclaves (Fig. 2b-d) and metasedimentary xenoliths (porcellanite, calc-silicate rocks) $1-50 \mathrm{~cm}$ in size. The subvolcanic intrusive rocks are often affected by post- 
Tab. 1 Locations, generalized mineralogy and $\mathrm{P}-\mathrm{T}$ conditions of the studied samples of subvolcanic rocks

\begin{tabular}{|c|c|c|c|c|c|c|}
\hline Sample & $\mathrm{O} 02 \mathrm{E}, \mathrm{V} 11, \mathrm{~V} 2, \mathrm{~V} 5$ & O01 & O01 & $\mathrm{O} 03$ & O01 & $\mathrm{O} 02 \mathrm{~A}, \mathrm{~V} 11 \mathrm{~b}, \mathrm{~V} 2 \mathrm{~b}, \mathrm{~V} 5 \mathrm{~b}$ \\
\hline Rock & Trachydacite & Trachyandesite & Trachyandesite & Trachybasalt & Basalt enclave & Gabbro enclave \\
\hline $\mathrm{SiO}_{2}$ (wt. \%) WR & 61.68 & 57.57 to 59.14 & 57.57 & 47.77 & - & 44.23 to 46.39 \\
\hline Locality & Komňa & Bojkovice & Bojkovice & Bánov & Bojkovice & Komňa \\
\hline Latitude & $\mathrm{N} 48^{\circ} 58.856^{\prime}$ & $\mathrm{N} 49^{\circ} 02.119^{\prime}$ & $\mathrm{N} 49^{\circ} 02.119^{\prime}$ & $\mathrm{N} 48^{\circ} 58.669^{\prime}$ & $\mathrm{N} 49^{\circ} 02.119^{\prime}$ & $\mathrm{N} 48^{\circ} 58.856^{\prime}$ \\
\hline Longitude & $\mathrm{E} 017^{\circ} 47.493^{\prime}$ & E01748.167' & $\mathrm{E} 017^{\circ} 48.167^{\prime}$ & $\mathrm{E} 017^{\circ} 43.910^{\prime}$ & E01748.167' & E0174․493' \\
\hline Mineral assemblage & $\begin{array}{l}\text { Pl, Kfs, Bt, Amp, } \\
\text { Mgt, Ilm, Ttn, Ap }\end{array}$ & $\begin{array}{l}\text { Pl, Kfs, Amp, Cpx, } \\
\text { Mgt, Ilm, Ttn, Ap }\end{array}$ & $\begin{array}{l}\text { core of Amp } \\
\text { phenocrysts }\end{array}$ & $\begin{array}{c}\text { Pl, Amp, Cpx, } \\
\text { Ttn, Ap }\end{array}$ & $\begin{array}{c}\text { Pl, Amp, Cpx, Bt, } \\
\text { Mgt, Ap }\end{array}$ & $\begin{array}{c}\text { Amp, Pl, Bt, Cpx, Ap, } \\
\text { Ilm, Mgt }\end{array}$ \\
\hline \multicolumn{7}{|l|}{ Amphibole } \\
\hline $\mathrm{X}_{\mathrm{Mg}}$ & 0.69 to 0.86 & 0.52 to 0.71 & 0.52 to 0.86 & 0.72 to 0.84 & 0.51 to 0.75 & 0.60 to 0.82 \\
\hline $\mathrm{Si}(\mathrm{apfu})$ & 6.12 to 6.55 & 5.91 to 6.10 & 5.91 to 6.55 & 5.95 to 6.00 & 5.78 to 5.87 & 5.99 to 6.35 \\
\hline $\mathrm{Na}(\mathrm{apfu})$ & 0.52 to 0.68 & 0.69 to 0.77 & 0.52 to 0.77 & 0.64 to 0.69 & 0.66 to 0.71 & 0.54 to 0.76 \\
\hline \multicolumn{7}{|c|}{ Amphibole thermobarometry (Ridolfi et al. 2010) } \\
\hline $\mathrm{T}\left({ }^{\circ} \mathrm{C}\right)$ & 928 to 962 & 975 to 1037 & 1035 to 1055 & 1026 to 1044 & 1045 to 1058 & 936 to 1023 \\
\hline Uncertainty $\left(\sigma_{\text {est }}\right)$ & 22 & 22 & 22 & 22 & 22 & 22 \\
\hline $\mathrm{P}(\mathrm{GPa})$ & 0.27 to 0.37 & 0.42 to 0.67 & 0.70 to 0.74 & 0.55 to 0.60 & 0.71 to 0.86 & 0.33 to 0.56 \\
\hline $\begin{array}{l}\text { Uncertainty } \\
\text { (Max. error) }\end{array}$ & 0.03 to 0.04 & 0.05 to 0.07 & 0.08 & 0.06 & 0.08 to 0.09 & 0.04 to 0.06 \\
\hline DNNO & 0.2 to 1.2 & -1.1 to 0.3 & 0.1 to 0.7 & 0.0 to 0.7 & -0.9 to 0.1 & -0.3 to 0.5 \\
\hline $\log \mathrm{fO}_{2}$ & -10.9 to -10.0 & -11.3 to -9.6 & -9.5 to -8.5 & -9.7 to -8.8 & -10.3 to -9.1 & -11.0 to -9.7 \\
\hline Uncertainty $\left(\sigma_{\text {est }}\right)$ & 0.4 & 0.4 & 0.4 & 0.4 & 0.4 & 0.4 \\
\hline $\mathrm{H}_{2} \mathrm{O}$ melt (wt. $\%$ ) & 4.6 to 5.9 & 4.5 to 6.6 & 5.8 to 6.5 & 5.3 to 5.9 & 6.2 to 7.4 & 5.4 to 6.1 \\
\hline Uncertainty* & 0.7 to 0.8 & 0.7 to 1.0 & 0.9 to 1.0 & 0.8 to 0.9 & 0.9 to 1.1 & 0.8 to 0.9 \\
\hline \multicolumn{7}{|c|}{ Amphibole thermobarometry (Ridolfi and Renzulli 2012) } \\
\hline $\mathrm{T}\left({ }^{\circ} \mathrm{C}\right)$ & 885 to 965 & 949 to 993 & 979 to 986 & 966 to 1004 & 957 to 988 & 899 to 1015 \\
\hline $\mathrm{P}(\mathrm{GPa})$ & 0.32 to 0.45 & 0.48 to 1.25 & 0.84 to 0.91 & 0.50 to 0.79 & 0.63 to 0.87 & 0.30 to 0.90 \\
\hline DNNO & -0.1 to 3.0 & 1.7 to 4.0 & 3.1 to 5.0 & 2.0 to 4.0 & 1.8 to 3.4 & -0.5 to 3.0 \\
\hline $\mathrm{H}_{2} \mathrm{O}$ melt (wt. $\left.\%\right)$ & 5.2 to 7.4 & 6.3 to 10.4 & 9.1 to 8.5 & 5.8 to 7.0 & 8.1 to 8.7 & 5.2 to 6.9 \\
\hline \multicolumn{7}{|c|}{ P-independent amphibole-liquid thermometry - equation 5 and barometer - equation $7 b$ (Putirka 2016) } \\
\hline $\mathrm{T}\left({ }^{\circ} \mathrm{C}\right)$ & 940 to 963 & 966 to 1026 & - & 1010 to 1026 & - & cumulate \\
\hline $\mathrm{P}(\mathrm{GPa})$ & 0.32 to 0.39 & 0.39 to 0.60 & - & 0.60 to 0.63 & - & cumulate \\
\hline \multicolumn{7}{|c|}{ Plagioclase-liquid thermometer - equation 24a, hygrometer - equation 25b (Putirka 2008) } \\
\hline $\mathrm{T}\left({ }^{\circ} \mathrm{C}\right)$ & 929 to 944 & 988 to 1022 & - & 1005 to 1017 & - & cumulate \\
\hline $\mathrm{H}_{2} \mathrm{O}$ melt (wt.\%) & 4.9 to 5.4 & 4.3 to 4.9 & - & 4.4 to 5.5 & - & cumulate \\
\hline \multicolumn{7}{|c|}{ Plagioclase-liquid barometer 25a (Putirka 2005, 2008) } \\
\hline $\mathrm{P}(\mathrm{GPa})$ & 0.28 to 0.34 & 0.52 to 0.83 & - & 0.38 to 0.97 & & cumulate \\
\hline \multicolumn{7}{|c|}{ Amphibole-liquid thermometry (Molina et al. 2015) } \\
\hline $\mathrm{T}\left({ }^{\circ} \mathrm{C}\right)$ & 951 to 959 & 903 to 921 & - & 945 to 957 & - & cumulate \\
\hline \multicolumn{7}{|c|}{ Plagioclase-hornblende thermometry (Holland and Blundy 1994) } \\
\hline $\mathrm{T}\left({ }^{\circ} \mathrm{C}\right)$ & 875 to 901 & 834 to 950 & - & 891 to 992 & 865 to 893 & 922 to 1009 \\
\hline \multicolumn{7}{|l|}{ Clinopyroxene } \\
\hline $\mathrm{X}_{\mathrm{Mg}}$ & - & 0.65 to 0.84 & - & 0.77 to 0.83 & 0.65 to 0.66 & 0.67 to 0.79 \\
\hline $\mathrm{Ca}$ (apfu) & - & 0.91 to 0.94 & - & 0.91 to 0.95 & 0.93 to 0.94 & 0.85 to 0.89 \\
\hline K-feldspar (Ab) & 8 to 35 & 49 to 59 & - & - & - & $8 * *$ \\
\hline Plagioclase (An) & 30 to $53\left(0\right.$ to $\left.10^{*}\right)$ & 31 to 63 & 59 to 83 & 30 to 89 & 35 to 83 & 37 to $84\left(1\right.$ to $\left.21^{*}\right)$ \\
\hline Ilmenite (Mn, apfu) & 0.47 to 0.48 & 0.34 to 0.44 & - & - & - & 0.52 to $0.68^{*}$ \\
\hline
\end{tabular}

* result of secondary (hydrothermal) alteration

** very rarely

$\mathrm{WR}=$ whole-rock analysis

magmatic alteration (Přichystal 1974). Hydrothermal alteration is restricted to relatively narrow zones along faults, except for the trachydacite body at Bučník near Komňa which is almost entirely overprinted by a variable degree of propylitization accompanied by sulfidic $\mathrm{Fe}-\mathrm{Cu}-\mathrm{Zn}-\mathrm{Pb}-\mathrm{Hg}$ mineralization (Černý 1958; Fojt and Přichystal 1979).

\section{Analytical techniques}

\subsection{Electron microprobe}

Electron-microprobe analyses (EMPA) were performed on the Cameca SX-100 instrument in the Joint Laboratory of Electron Microscopy and Microanalysis of Masaryk 

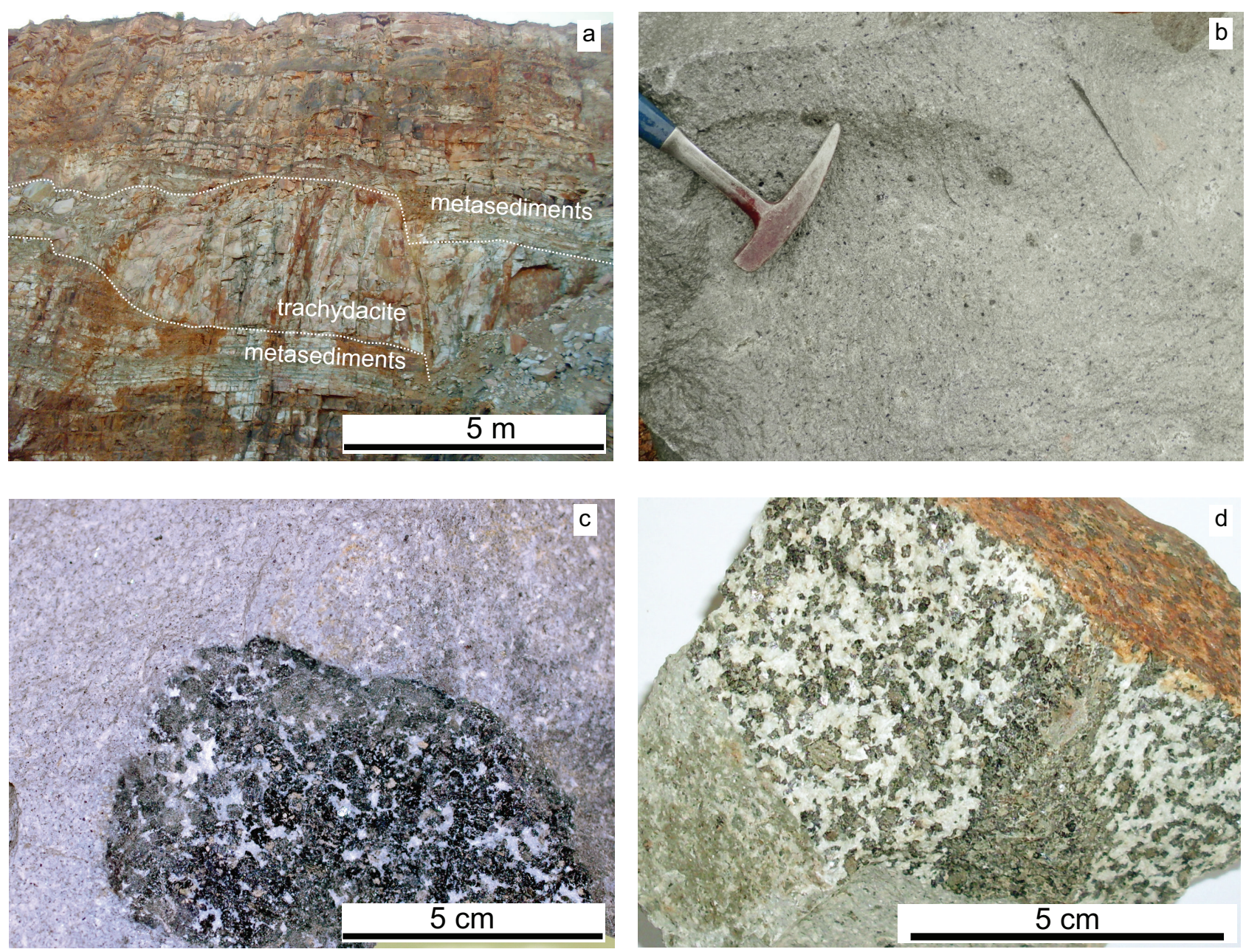

Fig. 2 Macrophotographs from Bučník Hill quarry: a - Part of the cedar-tree laccolith exposed in the quarry on the Bučník Hill (photo Michaela Hašková); b - Trachybasalt enclaves in trachyandesite from the Bučník Hill; c - Gabbro enclave in trachydacite; $\mathbf{d}$ - Leucocratic and melanocratic enclave in trachyandesite (photo Michaela Hašková).

University and the Czech Geological Survey (Brno, Czech Republic) by R. Čopjaková. The measurements were carried out in wavelength-dispersive mode under the following conditions: accelerating voltage $15 \mathrm{kV}$, beam current $10 \mathrm{nA}$ and beam diameter 3-8 $\mu \mathrm{m}$. Natural and synthetic standards were used $(\mathrm{Si}, \mathrm{Al}$ - sanidine; $\mathrm{Mg}-$ olivine; $\mathrm{Fe}$ - almandine; $\mathrm{Ca}$ - andradite; $\mathrm{Mn}$ - rhodonite; $\mathrm{Ti}$ - Ti-hornblende; $\mathrm{Cr}$ - chromite; $\mathrm{Na}$ - albite; $\mathrm{K}$ - orthoclase; $\mathrm{P}$ - apatite; $\mathrm{F}$ - topaz; $\mathrm{Cl}, \mathrm{V}$ - vanadinite; $\mathrm{Zn}$ - gahnite; $\mathrm{Cu}$ - metallic $\mathrm{Cu}$; Y - YAG). The raw concentration data were corrected using the method of Pouchou and Pichoir (1985). Representative electron-microprobe analyses of amphibole, plagioclase and clinopyroxene are given in electronic supplementary materials (ESM) 1-3.

The empirical formulae (all $\mathrm{Fe}$ as $\mathrm{Fe}^{2+}$ ) of feldspars and biotites were calculated to 8 and 22 oxygen atoms, respectively. The amphibole formulae were calculated on the basis of 23 oxygen atoms; all analyses can be classified as calcic amphiboles (Leake et al. 1997). The $\mathrm{Fe}^{2+} / \mathrm{Fe}^{3+}$ ratios were estimated on the basis of 13 total cations excluding $\mathrm{Ca}, \mathrm{Na}$ and $\mathrm{K}$. Clinopyroxene analyses were recalculated on the basis of $6 \mathrm{O}$ and Fe oxidation state was assessed using the $\mathrm{Fe}^{3+}$ model of Droop (1987). Mineral name abbreviations used in the text correspond to Kretz (1983) and Whitney and Evans (2010).

\subsection{Whole-rock geochemistry}

The eleven new rock samples collected in the field from three locations (Komňa, Bánov, Bojkovice) were cleaned of weathered surfaces (by chipping off using a hammer) resulting in 3 to $4 \mathrm{~kg}$ of fresh material. The rock samples were crushed in a steel jaw crusher (to $<5 \mathrm{~mm}$ ) and powdered in an agate ball mill. New whole-rock chemical analyses were performed at Acme Analytical Laboratories, Vancouver, Canada (Tab. 2a-b). Major-element oxides were analysed by the ICP-MS method. Loss on ignition (LOI) was calculated as weight difference after ignition at $1000^{\circ} \mathrm{C}$. The rare-earth and other trace elements were analysed by INAA and ICP-MS following 
$\mathrm{LiBO}_{2}$ fusion. These new data were supplemented by older data from the same laboratory (Nejbert et al. 2012; Hrouda et al. 2015) and also analyses obtained in the laboratories of the Czech Geological Survey in Prague (Krejčí et al. 1990; Fediuk and Gürtlerová 2006). Some data presented in this article are from Hašková (2018). Geochemical data were handled and plotted using the GCDkit software package (Janoušek et al. 2006). The fractional crystallization and magma mixing were interpreted in MS Excel spreadsheet using a FC-AFC-FCA and mixing model (Ersoy and Helvaci 2010).

\subsection{Thermobarometry, oxygen fugacity in the magma}

Temperature, pressure and $\mathrm{fO}_{2}$ estimates are based predominantly on the thermobarometric formulations empirically derived for amphibole by Ridolfi et al. (2010) and Ridolfi and Renzulli (2012). The temperature (T) estimation in their formulation is controlled by ${ }^{\mathrm{T}} \mathrm{Si}$ and ${ }^{\mathrm{T}} \mathrm{Ti}$ and pressure (P) estimation depends on $\mathrm{Al}$ content in the amphibole. To estimate amphibole crystallization pressure using the Ridolfi and Renzulli (2012) model, we calculated all five equations (1a to $1 \mathrm{e}$ ) and subsequently selected most appropriate result as outlined by those authors.

The reliability of the calculated temperatures has been examined by comparing the results from the Ridolfi et al. (2010) model with thermometers based on element partitioning between amphibole and plagioclase (Holland and Blundy 1994; Molina et al. 2015) and amphibole and silicate melt (Putirka 2016). The results of amphibole-plagioclase thermometer of Holland and Blundy (1994) were corrected for the pressure obtained by the Ridolfi et al. (2010) barometer. For the mineral assemblages lacking quartz we use the model B of Holland and Blundy (1994) thermometer, while for trachydacite we employ model A that is appropriate for quartz-rich mineral assemblages.

\section{Results}

\subsection{Petrography}

For this study we selected the main subvolcanic rock types according to their petrological features as summarized by Krystek (1955, 1958), Přichystal (1998), Shrbený (1974), Nejbert et al. (2012) and Hrouda et al. (2015).

\subsubsection{Amphibole to clinopyroxene-amphibo- le trachybasalts}

Amphibole to clinopyroxene-amphibole trachybasalts are porphyritic, fine-grained rocks with 10 to 35 vol. \% of phenocrysts (O3; Tab. 1). The dominant component is commonly plagioclase (up to 30 vol. \%) and rarely amphibole (up to 20 vol. \%). Clinopyroxene phenocrysts (diopside; $\mathrm{X}_{\mathrm{Mg}}$ 0.77-0.83; Fig. 3a-b) or carbonate pseudomorphs after olivine are only rarely present. Groundmass comprises altered glass (mainly clay minerals) with subhedral to anhedral plagioclase and amphibole. Plagioclase $\left(\mathrm{An}_{30-89}\right.$; Fig. $\left.3 \mathrm{c}\right)$ phenocrysts (up to $4 \mathrm{~mm}$ long) form equant to tabular crystals with simple zoning (normal zoning pattern); partially resorbed plagioclase cores are in several instances visible (sieve texture).

Tab. 2a Representative major-element (wt. \%) whole-rock chemical analyses from the subvolcanic rocks

\begin{tabular}{|c|c|c|c|c|c|c|c|c|c|c|c|}
\hline Sample & O01 & $\mathrm{O} 03$ & $\mathrm{O} 02$ & $\mathrm{~V} 2$ & V5 & TA-BK-3 & TA-BK-4 & $\mathrm{V} 2$ & V5 & XE-3 & XE-4 \\
\hline Rocks & TA & TB & TD & TA & TA & TA & TD & GE & GE & GE & GE \\
\hline Locality & Bojkovice & Bánov & Komňa & Komňa & Komňa & Komňa & Komňa & Komňa & Komňa & Komňa & Komňa \\
\hline $\mathrm{SiO}_{2}$ & 57.57 & 47.77 & 61.68 & 57.23 & 59.14 & 59.34 & 61.57 & 44.23 & 46.39 & 45.78 & 45.70 \\
\hline $\mathrm{TiO}_{2}$ & 0.68 & 1.54 & 0.64 & 0.80 & 0.70 & 0.68 & 0.67 & 1.93 & 1.40 & 1.46 & 1.31 \\
\hline $\mathrm{Al}_{2} \mathrm{O}_{3}$ & 18.75 & 17.13 & 17.02 & 17.26 & 17.22 & 17.18 & 16.84 & 16.43 & 18.74 & 15.42 & 17.15 \\
\hline $\mathrm{Fe}_{2} \mathrm{O}_{3}$ & 5.00 & 8.22 & 4.41 & 2.95 & 2.32 & 2.64 & 3.27 & 10.57 & 9.29 & 10.11 & 8.95 \\
\hline $\mathrm{MnO}$ & 0.17 & 0.16 & 0.13 & 0.07 & 0.06 & 0.07 & 0.06 & 0.21 & 0.21 & 0.17 & 0.17 \\
\hline $\mathrm{MgO}$ & 1.44 & 4.56 & 2.00 & 2.26 & 2.03 & 1.82 & 1.84 & 6.82 & 5.68 & 8.20 & 6.29 \\
\hline $\mathrm{CaO}$ & 5.40 & 8.96 & 4.03 & 8.01 & 7.57 & 6.91 & 5.88 & 10.94 & 9.49 & 12.56 & 10.70 \\
\hline $\mathrm{Na}_{2} \mathrm{O}$ & 4.93 & 3.03 & 4.46 & 4.27 & 3.87 & 3.84 & 4.35 & 3.16 & 3.48 & 2.34 & 2.78 \\
\hline $\mathrm{K}_{2} \mathrm{O}$ & 3.44 & 1.78 & 3.39 & 3.16 & 4.59 & 4.78 & 3.47 & 1.09 & 0.63 & 0.98 & 0.77 \\
\hline $\mathrm{P}_{2} \mathrm{O}_{5}$ & 0.32 & 0.47 & 0.38 & 0.46 & 0.40 & 0.39 & 0.37 & 1.35 & 0.73 & 0.58 & 0.60 \\
\hline $\mathrm{Cr}_{2} \mathrm{O}_{3}$ & $<0.002$ & 0.007 & 0.004 & 0.003 & $<0.002$ & 0.002 & 0.002 & 0.006 & 0.004 & 0.015 & 0.029 \\
\hline LOI & 1.90 & 6.00 & 1.50 & 3.20 & 1.70 & 2.00 & 1.30 & 2.80 & 3.50 & 1.90 & 5.20 \\
\hline Sum & 99.60 & 99.62 & 99.64 & 99.78 & 99.76 & 99.74 & 99.70 & 99.58 & 99.65 & 99.60 & 99.67 \\
\hline $\mathrm{mg \#}$ & 36.3 & 52.4 & 47.3 & 60.3 & 63.4 & 57.7 & 52.7 & 56.1 & 54.8 & 61.6 & 58.2 \\
\hline $\mathrm{K}_{2} \mathrm{O} / \mathrm{Na}_{2} \mathrm{O}$ (wt. \%) & 0.70 & 0.59 & 0.76 & 0.74 & 1.19 & 1.24 & 0.80 & 0.34 & 0.18 & 0.42 & 0.28 \\
\hline
\end{tabular}

Rock types: TD - trachydacite, TA - trachyandesite, TB - trachybasalt, GE - gabbro enclaves

Sample locations are in Tab. 1 
Tab. 2b Representative trace-element (ppm) chemical analyses from the studied subvolcanic rocks and gabbro enclaves

\begin{tabular}{|c|c|c|c|c|c|c|c|c|c|c|c|}
\hline Sample & O01 & $\mathrm{O} 03$ & $\mathrm{O} 02$ & $\mathrm{~V} 2$ & V5 & TA-BK-3 & TA-BK-4 & $\mathrm{V} 2$ & V5 & XE-3 & $\mathrm{XE}-4$ \\
\hline $\mathrm{Sc}$ & 6 & 27 & 8 & 11 & 8 & 7 & 8 & 30 & 27 & 47 & 35 \\
\hline $\mathrm{Be}$ & 3 & $<1$ & 2 & $<1$ & 3 & 1 & 2 & 2 & 1 & $<1$ & $<1$ \\
\hline V & 111 & 258 & 81 & 95 & 91 & 95 & 85 & 379 & 305 & 333 & 272 \\
\hline $\mathrm{Co}$ & 9.0 & 25.0 & 9.9 & 7.6 & 11.1 & 10.6 & 10.0 & 36.8 & 26.6 & 34.9 & 29.5 \\
\hline $\mathrm{Ni}$ & 4.2 & 14.9 & 14.8 & 15.9 & 18.4 & 13.3 & 11.6 & 17.2 & 14.1 & 22.6 & 28.1 \\
\hline $\mathrm{Cu}$ & 23.7 & 66.6 & 28.1 & 57.2 & 45.8 & 80.5 & 95.0 & 23.0 & 14.9 & 8.2 & 15.9 \\
\hline $\mathrm{Zn}$ & 56 & 53 & 94 & 21 & 21 & 173 & 625 & 55 & 106 & 436 & 92 \\
\hline $\mathrm{Ga}$ & 19.7 & 16.4 & 17.5 & 20.0 & 18.8 & 18.4 & 18.5 & 19.4 & 20.6 & 15.6 & 19.8 \\
\hline As & 0.9 & $<0.5$ & $<0.5$ & 1.8 & 3.3 & 4.7 & 4.7 & 2.0 & 1.8 & 4.4 & 2.0 \\
\hline $\mathrm{Rb}$ & 127.9 & 39.0 & 128.7 & 117.8 & 160.5 & 160.6 & 117.8 & 23.0 & 13.5 & 60.8 & 21.0 \\
\hline $\mathrm{Sr}$ & 1028.3 & 834.2 & 786.6 & 880.5 & 934.6 & 899.3 & 804.5 & 1024.9 & 1080.6 & 744.0 & 955.1 \\
\hline $\mathrm{Y}$ & 20.6 & 20.6 & 11.9 & 16.3 & 16.3 & 16.4 & 14.1 & 37.0 & 20.7 & 19.5 & 22.3 \\
\hline $\mathrm{Zr}$ & 264.7 & 116.0 & 196.8 & 196.2 & 221.8 & 225.3 & 227.7 & 136.7 & 108.4 & 95.8 & 97.5 \\
\hline $\mathrm{Nb}$ & 119.2 & 34.4 & 42.0 & 31.1 & 44.2 & 47.3 & 44.1 & 83.6 & 38.0 & 25.8 & 32.1 \\
\hline Mo & 2.7 & 1.7 & 4.1 & 0.5 & 0.4 & 0.5 & 0.6 & 1.0 & 1.9 & 1.2 & 3.4 \\
\hline $\mathrm{Ag}$ & $<0.1$ & $<0.1$ & 0.2 & $<0.1$ & 0.2 & 0.5 & 0.8 & 0.2 & 0.3 & $<0.1$ & 0.4 \\
\hline $\mathrm{Sn}$ & 1 & 1 & 2 & 3 & 3 & 4 & 3 & 3 & 2 & 2 & 3 \\
\hline $\mathrm{Sb}$ & $<0.1$ & $<0.1$ & 0.5 & 0.5 & 0.6 & 1.1 & 1.6 & 0.5 & 1.4 & 0.8 & 0.8 \\
\hline Cs & 3.9 & 1.2 & 1.6 & 2.1 & 2.9 & 2.5 & 2.4 & 1.3 & 2.9 & 14.4 & 2.7 \\
\hline $\mathrm{Ba}$ & 1655 & 830 & 1168 & 769 & 1093 & 1165 & 1013 & 763 & 427 & 380 & 399 \\
\hline $\mathrm{La}$ & 98.7 & 47.5 & 63.0 & 35.0 & 55.9 & 58.4 & 60.0 & 95.3 & 51.0 & 39.5 & 43.2 \\
\hline $\mathrm{Ce}$ & 157.2 & 81.9 & 99.9 & 68.7 & 104.9 & 107.8 & 102.4 & 182.4 & 96.1 & 75.3 & 83.7 \\
\hline $\mathrm{Pr}$ & 14.87 & 8.28 & 9.39 & 7.93 & 11.25 & 11.38 & 10.59 & 21.28 & 11.06 & 8.87 & 9.90 \\
\hline $\mathrm{Nd}$ & 45.3 & 31.5 & 33.0 & 27.9 & 37.7 & 37.3 & 35.3 & 79.1 & 42.0 & 35.2 & 38.8 \\
\hline $\mathrm{Sm}$ & 6.19 & 5.48 & 4.40 & 4.54 & 5.37 & 5.15 & 4.85 & 12.91 & 7.02 & 5.91 & 6.85 \\
\hline $\mathrm{Eu}$ & 1.75 & 1.61 & 1.17 & 1.50 & 1.52 & 1.52 & 1.40 & 3.27 & 2.03 & 1.83 & 1.90 \\
\hline $\mathrm{Gd}$ & 4.68 & 4.87 & 3.38 & 3.80 & 4.26 & 4.07 & 3.73 & 10.72 & 5.71 & 5.43 & 5.84 \\
\hline $\mathrm{Tb}$ & 0.70 & 0.71 & 0.44 & 0.56 & 0.56 & 0.54 & 0.49 & 1.44 & 0.77 & 0.74 & 0.81 \\
\hline Dy & 3.52 & 3.80 & 2.25 & 3.06 & 3.05 & 2.97 & 2.62 & 7.59 & 4.15 & 3.87 & 4.42 \\
\hline Ho & 0.73 & 0.75 & 0.42 & 0.60 & 0.60 & 0.59 & 0.48 & 1.43 & 0.77 & 0.74 & 0.81 \\
\hline $\mathrm{Er}$ & 2.17 & 2.06 & 1.26 & 1.73 & 1.78 & 1.66 & 1.37 & 3.82 & 2.05 & 2.01 & 2.09 \\
\hline $\mathrm{Tm}$ & 0.33 & 0.32 & 0.17 & 0.26 & 0.25 & 0.24 & 0.19 & 0.52 & 0.27 & 0.27 & 0.30 \\
\hline $\mathrm{Yb}$ & 2.35 & 1.93 & 1.29 & 1.65 & 1.75 & 1.67 & 1.38 & 3.11 & 1.72 & 1.74 & 1.73 \\
\hline $\mathrm{Lu}$ & 0.38 & 0.28 & 0.20 & 0.26 & 0.27 & 0.27 & 0.22 & 0.46 & 0.25 & 0.26 & 0.26 \\
\hline Hf & 5.7 & 2.9 & 5.3 & 4.6 & 4.9 & 5.0 & 5.2 & 3.8 & 2.8 & 2.6 & 2.8 \\
\hline $\mathrm{Ta}$ & 5.0 & 1.8 & 2.1 & 1.6 & 2.2 & 2.3 & 2.1 & 3.3 & 1.6 & 1.3 & 1.5 \\
\hline W & 1.2 & 1.4 & 2.9 & 4.2 & 3.1 & 3.3 & 2.2 & 2.1 & 2.6 & 1.5 & 2.3 \\
\hline $\mathrm{Tl}$ & $<0.1$ & $<0.1$ & $<0.1$ & $<0.1$ & $<0.1$ & $<0.1$ & $<0.1$ & 0.1 & 0.1 & 0.4 & 0.1 \\
\hline $\mathrm{Pb}$ & 5.6 & 2.0 & 51.2 & 9.3 & 16.8 & 50.3 & 38.3 & 9.4 & 36.5 & 3.9 & 68.9 \\
\hline $\mathrm{Bi}$ & $<0.1$ & $<0.1$ & $<0.1$ & $<0.1$ & $<0.1$ & $<0.1$ & $<0.1$ & $<0.1$ & 0.2 & 0.1 & 0.3 \\
\hline Th & 28.8 & 8.4 & 19.1 & 13.6 & 18.9 & 19.3 & 19.9 & 6.3 & 6.2 & 5.0 & 5.6 \\
\hline $\mathrm{U}$ & 7.8 & 2.2 & 5.5 & 3.2 & 4.2 & 4.8 & 4.1 & 1.7 & 1.8 & 1.4 & 1.6 \\
\hline $\mathrm{Eu} / \mathrm{Eu}^{*}$ & 0.99 & 0.95 & 0.93 & 1.10 & 0.97 & 1.02 & 1.01 & 0.85 & 0.98 & 0.99 & 0.92 \\
\hline $\mathrm{La}_{\mathrm{N}} / \mathrm{Yb}_{\mathrm{N}}$ & 28.3 & 16.6 & 32.9 & 14.3 & 21.5 & 23.6 & 29.3 & 20.7 & 20.0 & 15.3 & 16.8 \\
\hline Sum REE & 339 & 191 & 220 & 157 & 229 & 234 & 225 & 423 & 225 & 182 & 201 \\
\hline
\end{tabular}

The sample rock names are in Tab. $2 \mathrm{a}$.

Large phenocrysts also exhibit oscillatory zoning. Prismatic amphibole phenocrysts are up to $9 \mathrm{~mm}$ long and may contain euhedral to subhedral crystals of diopside, magnetite, apatite and melt inclusions. Based on the classification of Leake et al. (1997), pargasite dominates over magnesiohastingsite (Fig. 3d; $\mathrm{X}_{\mathrm{Mg}}$ 0.72-0.84, Si 5.95-6.00). Rare is patchy zoning with rounded and partially resorbed cores.

\subsubsection{Biotite-amphibole to clinopyroxene- amphibole trachyandesites}

The predominant rock types are biotite-amphibole to clinopyroxene-amphibole trachyandesites (O1, V11, V2, V5; Tab. 1). These rocks are porphyritic with 10 to 25 vol. \% phenocrysts (Fig. 4a-b). The most abundant mineral is usually plagioclase (up to 20 vol. \%); how- 

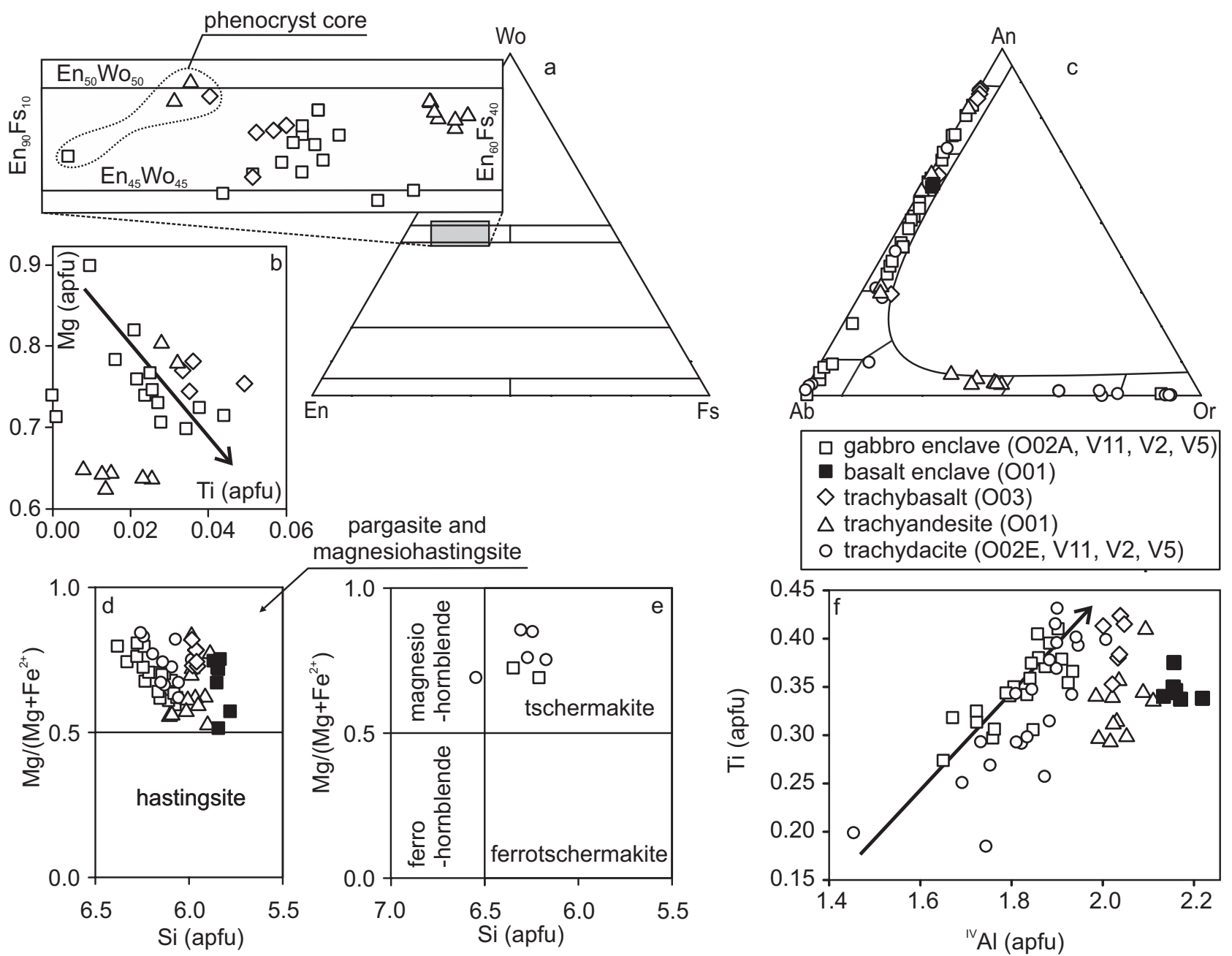

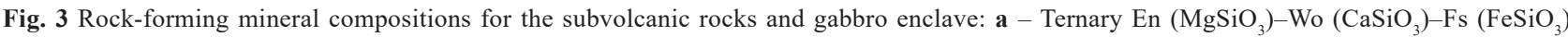
classification diagram (Morimoto et al. 1988); b - Mg vs. Ti diagram illustrating the clinopyroxene compositions; arrow shows approximately the direction of compositional shift due to fractional crystallization (e.g., Tracy and Robinson 1977; Rapprich et al. 2017); c - Ternary Ab-An-Or diagram (mol. \%) of feldspars; $\mathbf{d}-\mathbf{e}-\mathrm{Mg} /\left(\mathrm{Mg}+\mathrm{Fe}^{2+}\right.$ ) vs. Si (apfu) classification diagrams of calcic amphiboles with $\mathrm{Ca}{ }_{\mathrm{B}} \geq 1.5$ (Leake et al. 1997) containing $(\mathrm{Na}+\mathrm{K})_{\mathrm{A}} \geq 0.5$ and $(\mathrm{Na}+\mathrm{K})_{\mathrm{A}}<0.5$, respectively; $\mathbf{f}-\mathrm{Ti}$ vs. ${ }^{\mathrm{IV}} \mathrm{Al}$ diagram for calcic amphiboles; arrow shows approximately the direction of compositional shift due to fractional crystallization (e.g., Tiepolo et al. 2011).

ever, the rock can be locally enriched in clinopyroxene (diopside; Fig. 3a), amphibole (pargasite and magnesiohastingsite and tschermakite; Fig. 3d), and/or biotite with corroded crystal margins. Plagioclase phenocrysts are approximately $2 \mathrm{~mm}$ in size and form subhedral to euhedral elongated crystals with oscillatory zoning $\left(\mathrm{An}_{31-63}\right)$. A number of plagioclase phenocrysts have a sieve-textured or inclusion-rich (melt inclusions, amphibole, magnetite; Fig. 4a) cores. Amphibole phenocrysts $\left(\mathrm{X}_{\mathrm{Mg}}\right.$ 0.52-0.86, Si 5.91-6.55) often exhibit oscillatory zoning and rarely contain resorbed cores (Fig. 4b). There are very common small magnetite, apatite, plagioclase (Fig. 3c; $\mathrm{An}_{59-83}$ ) and melt inclusions within cores of the amphibole phenocrysts. Clinopyroxene phenocrysts are normally zoned. $\mathrm{X}_{\mathrm{Mg}}(0.65-0.84)$ shows a tendency to decrease towards the rim. The fine-grained groundmass consists of altered glass with subhedral to anhedral plagioclases and am- phibole crystallites. Euhedral groundmass plagioclases are normally zoned $\left(\mathrm{An}_{31-56}\right)$ and rarely contain a ternary feldspar core $\left(\mathrm{An}_{3-7} \mathrm{Or}_{34-48}\right)$. There is a locally distinct trachytic texture, with glomerophyric clusters of plagioclase phenocrysts and/or small carbonate amygdales. Apatite, magnetite (up to $20 \mathrm{~mol}$ \% of ulvöspinel component) and ilmenite are very common accessories. Ilmenite (Tab. 1) is partly replaced by titanite or leucoxene.

\subsubsection{Biotite-amphibole trachydacites to trachytes}

Trachydacites to trachytes (in the text called simply trachydacites) from the Bučník locality near Komňa (e.g., sample O2, Tab. 1) are porphyritic, with 10 to 30 vol. \% amphibole and/or plagioclase phenocrysts. Subhedral magnesiohastingsite is the predominant type of 

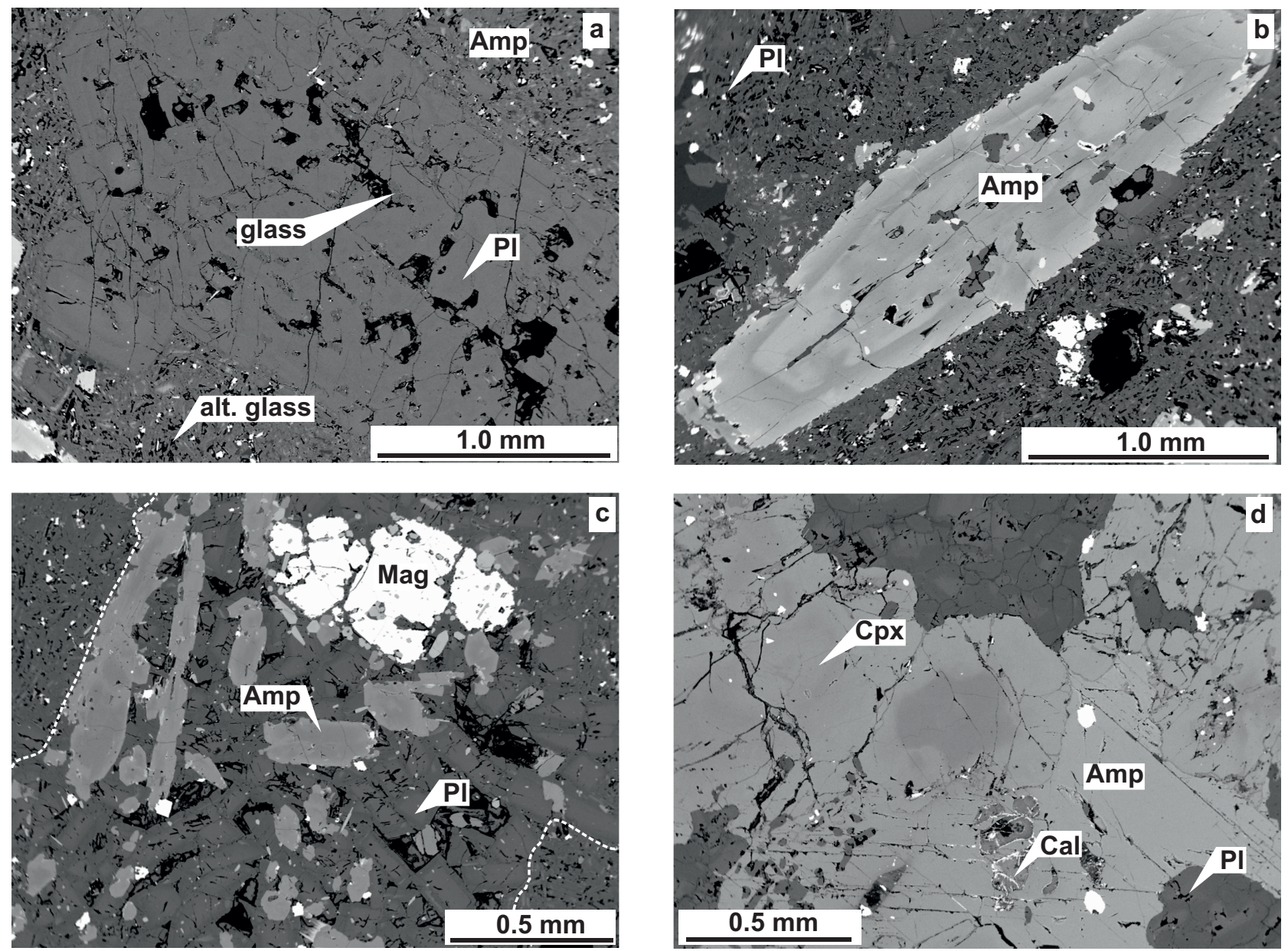

Fig. 4 Backscattered-electron images showing characteristic textures of trachyandesite sample O01 (a-b) basalt (O01) and gabbro (O02A) enclaves (c-d): a - Plagioclase phenocryst with sieve-textured core surrounded by fine-grained groundmass with ternary feldspar, amphibole and altered volcanic glass; $\mathbf{b}$-Amphibole phenocryst with corroded core; $\mathbf{c}$ - Basalt enclave composed of amphibole, plagioclase and magnetite in the trachyandesite (dashed line); $\mathbf{d}$ - Diopside and calcite pseudomorphs after olivine in amphibole of the gabbro enclave.

amphibole (Fig. 3d-f; $\mathrm{X}_{\mathrm{Mg}}$ 0.69-0.86, Si 6.12-6.55) and often contains small magnetite and apatite inclusions. Phlogopite $\left(\mathrm{X}_{\mathrm{Fe}} 0.36-40,{ }^{\mathrm{IV}} \mathrm{Al} 2.45-2.59\right)$ phenocrysts (up to $2 \mathrm{~mm}$ in size) are subhedral, commonly with altered and/or corroded crystal margins. Plagioclase phenocrysts $\left(\mathrm{An}_{30-53}\right)$ are partly replaced by albite and in many cases have rims or cracks filled by K-feldspar $\left(\sim \mathrm{Ab}_{8-35}\right)$. Subhedral to anhedral crystals of $\mathrm{K}$-feldspar are also common in the groundmass, together with quartz and albite.

\subsubsection{Enclaves}

The trachyandesite rarely encloses small (up to $3 \mathrm{~cm}$ long) basalt enclaves (Fig. 2b, 4c) consisting of normallyzoned euhedral plagioclase (Fig. $4 \mathrm{c})\left(\mathrm{An}_{35-84}\right)$ and subhedral amphibole $\left(\mathrm{X}_{\mathrm{Mg}}\right.$ 0.51-0.75, Si 5.78-5.87). Magnetite $\left(\mathrm{TiO}_{2} \sim 7.1\right.$ wt. \%) is a typical accessory.

The trachydacites locally contain medium- to coarsegrained leucocratic to melanocratic amphibole gabbro (Fig. 2c-d) enclaves (also rare granodiorites; Krystek
1955; Shrbený 1974) up to $70 \mathrm{~cm}$ in diameter. These enclaves are rounded and characterised by absence of chilled margins. The chemical compositions of the minerals in the leucocratic and melanocratic enclaves are almost identical. Enclaves have equigranular or poikilitic texture and predominantly consist of large subhedral amphibole (60 vol. \%) and euhedral to subhedral plagioclase (27 vol. \%). Plagioclase is present as phenocrysts or clusters of small grains (Fig. $4 \mathrm{~d})$ with simple zoning $\left(\mathrm{An}_{37-84}\right)$. There are very rare occurrences of subhedral $\mathrm{K}$-feldspar $\left(\mathrm{Ab}_{8}\right)$. The large amphibole (pargasite to magnesiohastingsite and tschermakite; $\mathrm{X}_{\mathrm{Mg}}$ 0.60-0.82, Si 5.99-6.35, Fig. 3d-f) grains (up to $1.5 \mathrm{~cm}$ ) form about 50 vol. $\%$ of the rock. They usually contain inclusions of euhedral to subhedral diopside (Fig. 3a; $\mathrm{X}_{\mathrm{Mg}}$ 0.67-0.79), subhedral to anhedral plagioclase $\left(\mathrm{An}_{69-75}\right)$, pyrrhotine and carbonate (calcite with siderite veins) pseudomorphs after olivine and/or orthopyroxene. Subhedral phlogopite $\left(\mathrm{X}_{\mathrm{Fe}} 0.37-0.43,{ }^{\mathrm{IV}} \mathrm{Al}\right.$ 2.44-2.55) up to $1 \mathrm{~mm}$ in size is present in a small amount ( 2 vol. \%). Diopside (7 vol. \%) has patchy or simple nor- 
mal zoning with $\mathrm{Cr}$ - and $\mathrm{Mg}$-rich cores (up to 0.029 and 0.899 apfu $\mathrm{Cr}$ and $\mathrm{Mg}$ ) respectively. Apatite is a typical accessory mineral (up to 3 vol. \%). Poikilitic textures as well as fine-grained plagioclase intercumulus are common within magmatic cumulates.

\subsubsection{Alteration}

Most of the studied rocks contain small amounts of volcanic glass that has been partly or completely altered to a mixture of chlorite and clay minerals. Small subhedral titanite crystals are also very common. Biotite phenocrysts are locally chloritized. Fine-grained secondary quartz becomes abundant mainly in the more altered samples containing disseminated ore grains (pyrite, chalcopyrite and sphalerite). Plagioclase in the fresh sample exhibits weak alteration, with development of white mica and clay minerals along cleavage, while altered samples contain plagioclase, which is partially replaced by albite (Tab. 1; $\left.\mathrm{An}_{0-21}\right)$. There are also local occurrences of secondary $\mathrm{K}$-feldspar $\left(\mathrm{Ab}_{8}\right)$. The pseudomorphs after olivine and/or orthopyroxene consist of talc, chlorite, Mn-rich ilmenite (Mn 0.52-0.68 apfu), magnetite and rare titanite.

\subsection{Variation in the chemical composition of clinopyroxene, amphibole and ilmenite}

In the conventional classification diagram (Morimoto et al. 1988), clinopyroxene compositions plot in the diopside field. Diopside phenocrysts usually display normal zoning with small Mg-rich cores and Fe-rich rims (Fig. 3a). Zoning is visible mainly in diopsides from the gabbro enclaves, which are characterized by core-to-rim decrease in $\mathrm{Al}(0.04-0.21 \mathrm{apfu})$ and $\mathrm{X}_{\mathrm{Mg}}$ and an increase in $\mathrm{Ti}$. The rims of diopside phenocrysts from trachyandesite have lower $\mathrm{X}_{\mathrm{Mg}}$ compared to phenocrysts in trachybasalt; however, the chemical compositions of the cores are similar.

The amphiboles from individual samples of basalt, trachybasalt and trachyandesite are chemically relatively homogeneous (Fig. 3d, f). However amphiboles from trachydacite and gabbro enclaves (pargasite to magnesiohastingsite and tschermakite) exhibit positive correlation between Ti and ${ }^{\mathrm{IV}} \mathrm{Al}$ (Fig. 3f).

Ilmenites (Tab. 1) from trachyandesite have low $\mathrm{Mn}$ (0.34-0.44 apfu) compared to trachydacite (Mn 0.47-0.48 apfu).

\subsection{Whole-rock geochemistry}

Based on petrography and TAS classification (LOI free basis; Le Bas et al. 1986; Le Maitre 2002), we can distinguish four main groups of rocks (Fig. 5a): (1) tra- chybasalts and basalts (basalts, trachybasalts, basaltic andesites, basaltic trachyandesites), (2) trachyandesites, (3) trachydacites (altered samples are classified as andesites) and (4) enclaves (gabbro according to petrography and basaltic chemistry, Fig. 5a).

The studied rocks have compositions transitional between alkaline and subalkaline rocks (Fig. 5a) and plot within the calc-alkaline field (Fig. 5b) of the triangular AFM diagram (Irvine and Baragar 1971). Subvolcanic rocks range from high-K calc-alkaline to shoshonitic while gabbro enclaves are rather calc-alkaline (Fig. 5cd). $\mathrm{SiO}_{2}$ contents range between 44.2 and 61.7 wt. $\%$; LOI varies from 0.5 to $7.7 \mathrm{wt}$. $\%$. The samples with high LOI (4.0-7.7 wt. \%) are enriched in clay minerals (from altered volcanic glass) compared to other samples (LOI of 0.5 to 3.5 wt. \%). Fresh and altered samples lie within same areas in the majority of the classification diagrams (Fig. 5a-d). However, any element or oxide exhibits a different content for altered and fresh samples in the variation diagrams (Fig. 6). The wide range in mg\# $(100 \times \mathrm{MgO} /(\mathrm{MgO}+\mathrm{FeO})$ in mol. $\%=20-65)$ indicates that the subvolcanic rocks underwent some fractionation and or mixing.

The variation diagrams (Fig. 6) show negative correlations of $\mathrm{SiO}_{2}$ with $\mathrm{FeO}_{t}, \mathrm{CaO}, \mathrm{TiO}_{2}$ and $\mathrm{P}_{2} \mathrm{O}_{5}$. On the other hand, $\mathrm{K}_{2} \mathrm{O}$ (Fig. 5b), $\mathrm{K}_{2} \mathrm{O} / \mathrm{Na}_{2} \mathrm{O}$ and $\mathrm{Rb}$ correlate positively with $\mathrm{SiO}_{2}$, and $\mathrm{Al}_{2} \mathrm{O}_{3} ; \mathrm{MgO}, \mathrm{Na}_{2} \mathrm{O}, \mathrm{Ba}, \mathrm{Sr}$ are scattered (Fig. 6).

Chondrite-normalized (Boynton 1984) REE patterns (Fig. 7a) exhibit relative enrichment in LREE and depletion in HREE contents $\left(\mathrm{La}_{\mathrm{N}} / \mathrm{Yb}_{\mathrm{N}}=14.3-38.6\right)$ with no significant $\mathrm{Eu}$ anomalies $\left(\mathrm{Eu} / \mathrm{Eu}^{*}=0.9-1.1\right)$.

Upper Continental Crust-normalized (Taylor and McLennan 1995) trace-element patterns are enriched in $\mathrm{Nb}$, LREE, Sr, P, and Ti. The gabbro enclaves are characterized by variable depletion in large-ion lithophile elements (LILE) ( $\mathrm{Rb}, \mathrm{Ba}, \mathrm{Th}, \mathrm{U}$, and $\mathrm{K}$ ) compared to volcanic rocks (Fig. 7b).

\section{4. $P-T-X$ conditions}

Chemical compositions of phenocrysts in volcanic rocks reflect the conditions during crystallization in the magma chamber and during ascent to the surface. Amphibole composition is sensitive to variations in pressure, oxygen fugacity, temperature, and melt composition (Tab. 1) during the crystallization of magma (e.g., Johnson and Rutherford 1989; Sato et al. 1999; Scaillet and Evans 1999; Rutherford and Devine 2003; Ridolfi et al. 2010; Ridolfi and Renzulli 2012; Shane and Smith 2013).

We focused mainly on the amphibole thermobarometric formulations of Ridolfi et al. (2010), because they can be applied to hybrid and re-homogenized magmas (e.g., Ridolfi et al. 2010; Laeger et al. 2013). All the 

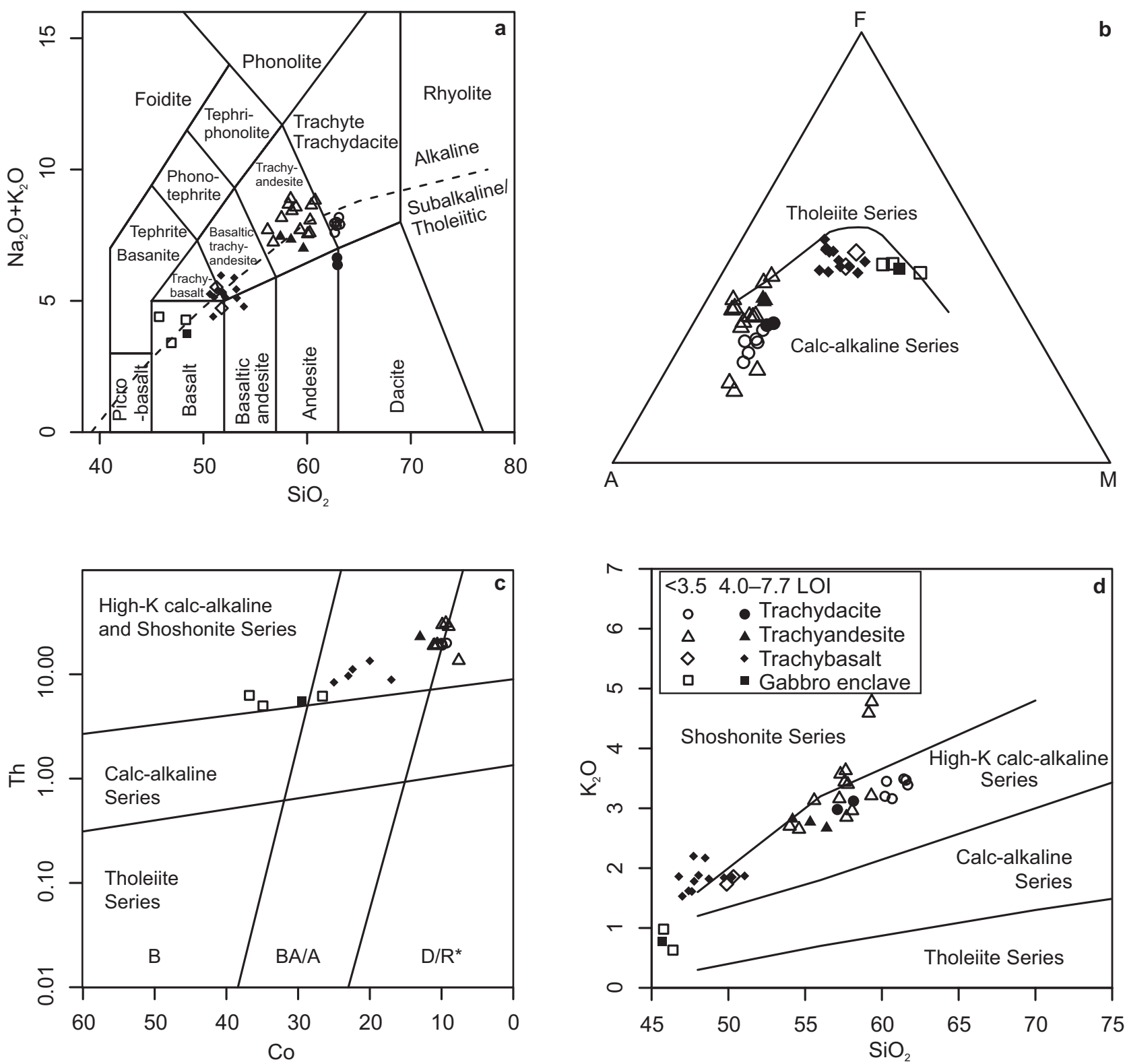

Fig. 5 Geochemical characterization of the subvolcanic rocks from southeastern Moravia: a - Total alkali vs. silica (TAS) diagram after Le Bas et al. (1986); b - AFM diagram (Irvine and Baragar 1971), $\mathrm{A}=\left(\mathrm{K}_{2} \mathrm{O}+\mathrm{Na}_{2} \mathrm{O}\right), \mathrm{F}=\mathrm{FeO}_{\mathrm{t}}, \mathrm{M}=\mathrm{MgO}$ (wt. \%); $\mathbf{c}-\mathrm{Th}$ vs. Co diagram (Hastie et al. 2007), $\mathrm{B}=$ basalt, $\mathrm{BA} / \mathrm{A}=$ basaltic-andesite and andesite, $\mathrm{D} / \mathrm{R}^{*}$, dacite and rhyolite; $\mathbf{d}-\mathrm{K}_{2} \mathrm{O}$ vs. $\mathrm{SiO}_{2}$ diagram (Peccerillo and Taylor 1976).

studied rocks contain pargasites to magnesiohastingsites (Fig. 3d-f; Tab. 1) with relatively constant $\mathrm{Ti}$ and $\mathrm{Na}$ contents of $0.30-0.43$ and $0.63-0.77$ apfu, respectively. Amphiboles from trachybasalt and trachyandesite were equilibrated under higher P-T conditions (Tab. 1; $975-1055^{\circ} \mathrm{C}$ and $\left.0.42-0.74 \mathrm{GPa}\right)$ than those from trachydacite (Tab. $1 ; 928-962{ }^{\circ} \mathrm{C}$ and $0.27-0.37 \mathrm{GPa}$ ). The $\mathrm{P}-\mathrm{T}$ conditions obtained for the gabbro enclaves $\left(936-1023^{\circ} \mathrm{C}\right.$ and $0.33-0.56 \mathrm{GPa}$ ) overlap substantially with those of the host-rock (trachydacite, Tab. 1). Amphibole in basalt enclaves from trachyandesite yields a temperature range of $1045-1058^{\circ} \mathrm{C}$ and pressures of 0.71-0.86 GPa.
We used thermometers based on the equilibrium between two phases (Holland and Blundy 1994; Molina et al. 2015; Putirka 2016) to test the accuracy of the P-T conditions derived from the Ridolfi et al. (2010) formulation. We carried out the calculation using plagioclase inclusions in amphibole or rim compositions of small plagioclase grains that could have been contemporaneous with the amphibole crystallization (calibrations of Holland and Blundy 1994 and Molina et al. 2015). Nevertheless, this yielded slightly lower P-T conditions compared to the Ridolfi et al. (2010) formulation (Fig. 8a). The absolute differences of up to $89^{\circ} \mathrm{C}$ and up to 0.08 $\mathrm{GPa}$ are probably a result of subsolidus re-equilibration 

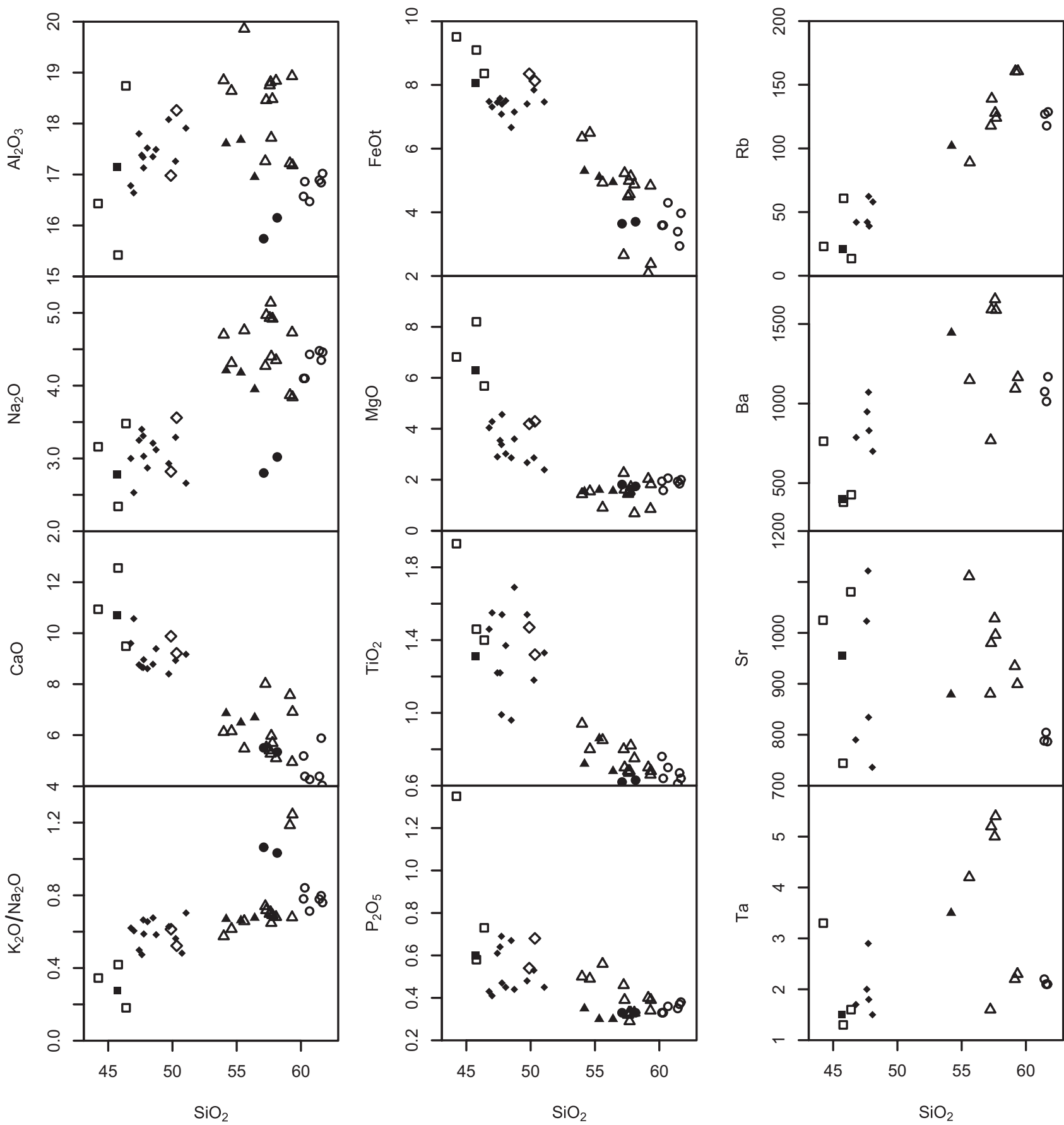

Fig. 6 Binary plots of selected major-element oxides and trace-elements vs. $\mathrm{SiO}_{2}$. Same symbols as in Fig. 5.

during cooling (e.g., Cornejo and Mahood 1997; Tetsopgang et al. 2011) or amphibole and plagioclase growth at different stages of the magmatic evolution. We must also remember that according Ridolfi et al. (2008), twophase thermometers can hardly be applicable to variously re-homogenized magmas, such as the studied group of subvolcanic rocks.

The Ridolfi et al. (2010) formulation also provides an estimate of the oxygen fugacity during the crystal- lization of amphibole. The similar amphibole compositions verify the similar oxygen fugacity (Fig. 8b) for all the studied samples from $\log \mathrm{fO}_{2}-8.8$ to -11.3 ( $\pm 0.4 \log$ units; equal to $\triangle \mathrm{NNO}$ (Nickel-Nickel Oxide buffer) -1.1 to +1.2 . Melt water contents (Tab. 1; Fig. 8c), estimated on the basis of the amphibole chemistry (Ridolfi et al. 2010), are highly variable for trachyandesite and trachydacite (4.4-6.6 wt. \%) and lie in a narrow range for trachybasalt (5.3-5.9 wt. \%). 

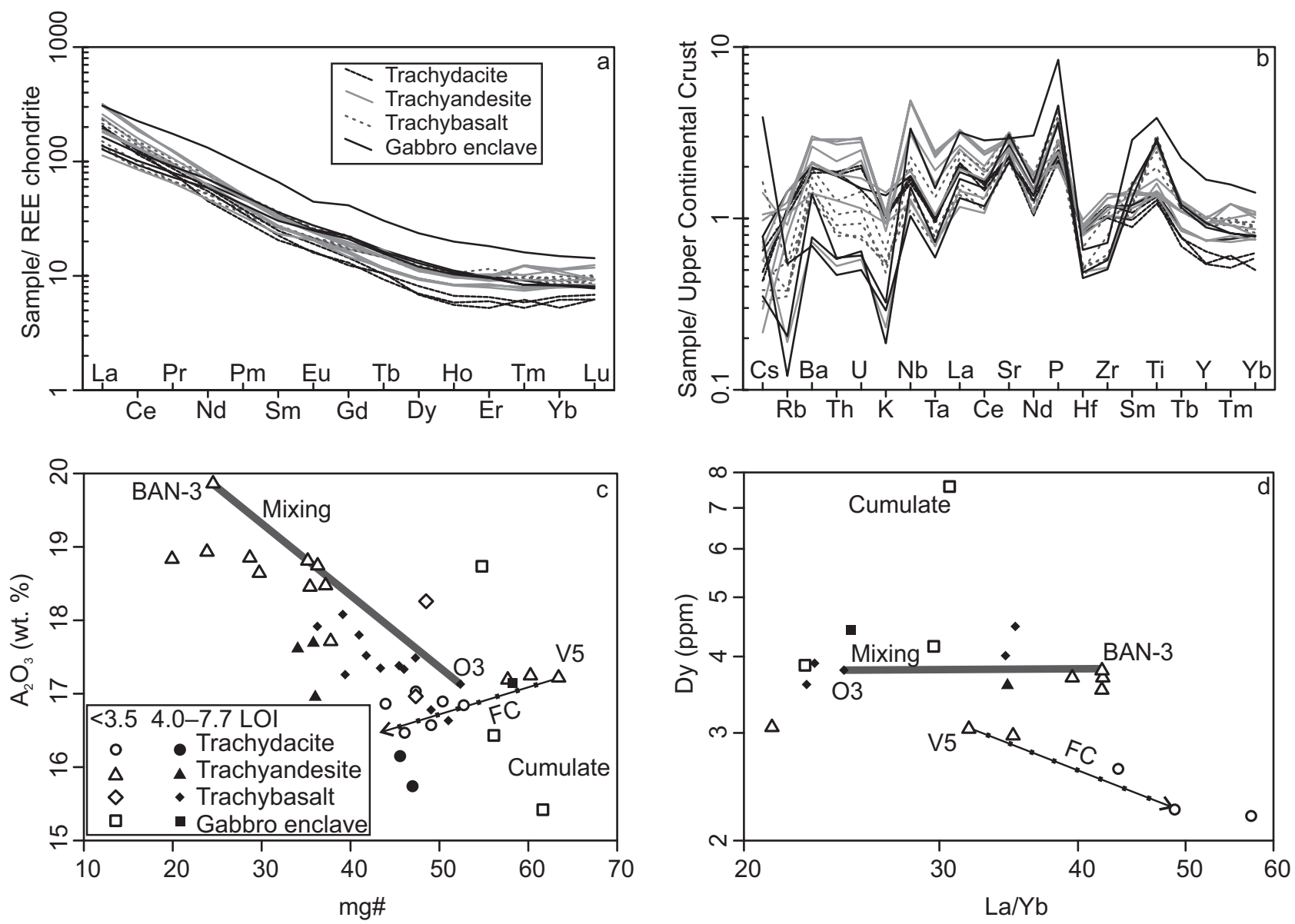

Fig. 7 Chondrite-normalized REE (a) and Upper Continental Crust-normalized trace-element (b) spidergrams of the subvolcanic rocks from southeastern Moravia. Normalization values for chondrite and Upper Continental Crust are from Boynton (1984) and Taylor and McLennan (1995), respectively. c - Diagram $\mathrm{Al}_{2} \mathrm{O}_{3}$ vs. mg\# (the black arrow shows the fractionation of rocks from the Bučník laccolith and thick gray line a mixing line between a trachyandesite: BAN-3 (Nejbert et al. 2012) and trachybasalt: O3); d - Diagram Dy vs. La/Yb with the same model trends. Geochemical modelling was performed by FC-AFC-FCA modeler of Ersoy and Helvac1 (2010) using partition coefficients for acid melt compositions. The assumed starting composition was that of sample V5, the least evolved sample from the Bučník laccolith. The assumed fractionating assemblage was plagioclase (35 wt. \%), K-feldspar (20\%), amphibole (20\%), biotite (15\%), clinopyroxene (10\%), ilmenite (1\%), magnetite $(1 \%)$, apatite $(0.5 \%)$, and zircon $(0.5 \%)$. Mineral proportions estimated according the average composition trachyandesites and trachydacites. Increments represent $2 \%$ and the trends terminate at $18 \%$ crystallization.

Water contents in the gabbro enclaves (5.4-6.1 wt. \%) are comparable with those in trachybasalt; however, the basalt enclaves have higher $\mathrm{H}_{2} \mathrm{O}$ contents $(6.2-7.4$ wt. \%).

We applied the Ghiorso and Evans (2008) model of the $\mathrm{Fe}-\mathrm{Ti}$ two-oxide thermometer and oxygenbarometer to the trachyandesite $\mathrm{O} 01$, yielding an $\mathrm{fO}_{2}$ of $\triangle \mathrm{NNO}+0.3$ to +0.4 . Similarly to the Ridolfi et al. (2010) formulation, it provides an estimate of the oxygen fugacity during the crystallization of amphibole (Tab. 1). The lower temperatures $\left(734\right.$ to $\left.809^{\circ} \mathrm{C}\right)$ can be explained as the result of late crystallization of ilmenite and magnetite in the groundmass, because much of groundmass crystallization can occur as a result of decompression during the magma ascent (Couch et al. 2003).

\section{Discussion}

\subsection{Magma sources and evolution}

According to previous work (Nejbert et al. 2012) the studied magmatic rocks were generated in the metasomatised lithosphere and were strongly influenced by infiltration of deeper metasomatised mantle-derived melts and/or fluids. $\mathrm{Nb} / \mathrm{Y}(1.4-5.8)$ and $\mathrm{Th} / \mathrm{Y}(0.4-1.6)$ in the studied volcanic rocks are higher than in the Carpathian-Pannonian region and Pieniny area (Seghedi and Downes 2011; Nejbert et al. 2012; Anczkiewicz and Anczkiewicz 2016) and can be interpreted as an indicator of a stronger enriched mantle signature (Nejbert et al. 2012). However, mainly trachydacites exhibit similar contents of many trace elements to the Upper Conti- 

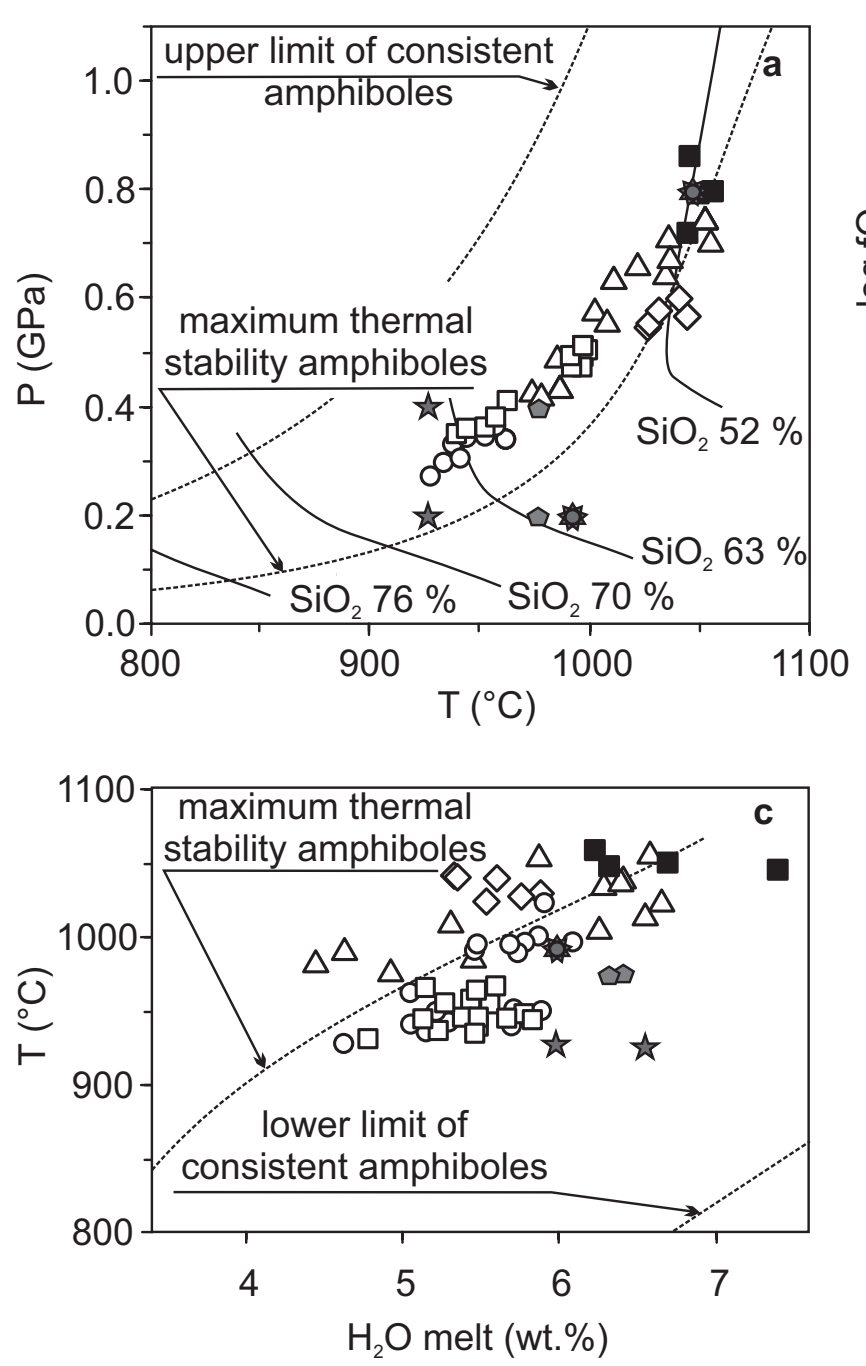

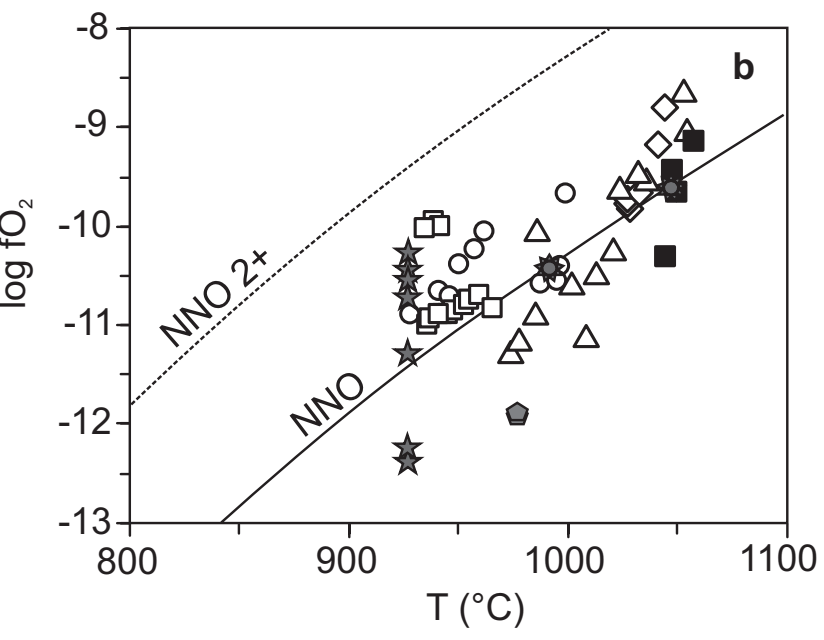

\begin{tabular}{|l}
$\diamond$ trachybasalt: $\mathrm{O} 03$ \\
$\Delta$ trachyandesite: $\mathrm{O} 01$ \\
0 trachydacite: O02A, V11, V2, V5 \\
basalt enclave: O01 \\
$\square$ gabbro enclave: O02A, V11, V2, V5 \\
Experimental data \\
Grove et al. (2003) basaltic andesite \\
(Amp + Cpx $+\mathrm{Sp} \pm \mathrm{PI} \pm \mathrm{OI})$ \\
Andújar et al. $(2015)$ basalt \\
(Amp + Cpx $+\mathrm{Mt}+\mathrm{PI}+\mathrm{OI})$ \\
Andújar et al. $(2016)$ andesite \\
(Amp + Cpx $+\mathrm{Mt} \pm \mathrm{PI} \pm \mathrm{IIm})$
\end{tabular}

Fig. 8 Crystallization conditions for the subvolcanic rocks from southeastern Moravia based on amphibole using the approach of Ridolfi et al. (2010): a - P vs. T diagram (isopleths show the anhydrous $\mathrm{SiO}_{2}$ (wt. \%) contents of the melt) and ranges of amphibole stability conditions are defined according to Ridolfi et al. (2010); b - log $\mathrm{fO}_{2}$ vs. T diagram with curves of the nickel-nickel oxide (NNO) buffer; $\mathbf{c}-\mathrm{T}$ vs. $\mathrm{H}_{2} \mathrm{O}$ in melt diagram.

nental Crust of Taylor and McLennan (1995) (Fig. 7b). Trachydacites and trachyandesites are characterized by high HFSE and LILE (e.g., Rb, Ba), and lower LILE/ HFSE ratios compared to the trachybasalts (Fig. 7b). The variation in the chemical composition of the studied subvolcanic rocks, as well as the presence of basalt and/or gabbro enclaves and disequilibrium phenocryst textures, indicates complicated evolution and the potentially important role of magma mingling, mixing and fractional crystallization (Nixon 1988; Ortoleva 1990; Dobosi and Fodor 1992). Unfortunately, most subvolcanic rocks have been affected by hydrothermal alteration, making geochemical modelling difficult. Based on the available data, we are able to interpret only the most fractionated members of this volcanic suite from the Bučník laccolith.

\subsection{Magma mixing}

The cores of normally and/or oscillatory-zoned clinopyroxene phenocrysts in the trachybasalts and trachyandesites are more Mg-rich $\left(\mathrm{X}_{\mathrm{Mg}}=0.83-0.84\right)$, compared to the rims. The similar composition of the same clinopyroxene phenocryst cores from trachyandesite and trachybasalt samples indicates that both were probably related to crystallization from the same mafic end-member of the magma mixing. On the other hand, phenocryst rims are characterized by simple weak zoning with $\mathrm{X}_{\mathrm{Mg}}$ ranging from 0.65 to 0.79 .

In the trachyandesite sample O01, complexly zoned plagioclase phenocrysts with partially resorbed cores containing abundant inclusions of amphibole and/or volcanic glass are present (Fig. 4a). This sieve texture 
is commonly attributed to the reaction between the plagioclase phenocrysts and higher-temperature mafic melt (e.g., Tsuchiyama 1985; Nakamura and Shimakita 1998).

The presence of basalt enclaves within trachyandesite sample O01 (Tab. 1) can be also interpreted as a result of magma mixing of basic and acidic end-members (e.g., Eichelberger 1975). The variation in the whole-rock $\mathrm{Al}_{2} \mathrm{O}_{3}$ vs. mg\# (Fig. 7c) of trachyandesite and trachybasalt samples could have been produced by mixing of low- and high-Mg magmas. Simple mixing calculations (Fig. 7c-d) indicate that the addition of mafic melt (chemical composition of trachybasalt O3) would produce regular changes in contents of some oxides and elements similar to the observed variation (e.g., $\mathrm{Al}_{2} \mathrm{O}_{3}$, $\mathrm{La} / \mathrm{Yb}$ ). This process can therefore be responsible for changes in the composition of some trachybasalts and trachyandesites (Fig. 6).

Amphiboles from basalt enclave within the trachyandesite show relatively high $\mathrm{P}-\mathrm{T}$ conditions $(0.71-0.86$ $\mathrm{GPa}$ and $1045-1058^{\circ} \mathrm{C}$ ), which can be interpreted as evidence for mixing and mingling in the magma chamber in the deeper crust $(\sim 20-30 \mathrm{~km})$.

\subsection{Fractional crystallization}

Compositional variation (Fig. 3) of minerals in the individual samples and general trends in the observed chemical composition of the plagioclase and amphibole phenocrysts (normally and/or oscillatory zoned, Fig. 4a-b) suggest significant control by crystal fractionation.

Plagioclase is the predominant mineral phase in most of the studied rocks. Plagioclases from the matrix of the trachybasalts are usually normally zoned from the labradorite-bytownite core $\left(\mathrm{An}_{62-89}\right)$ to the thin andesine rim $\left(\mathrm{An}_{30-31}\right)$; on the other hand, trachyandesites $\left(\mathrm{An}_{58-83}\right)$ and trachydacites $\left(\mathrm{An}_{35-44}\right)$ contain predominantly oscillatoryzoned plagioclase. This type of oscillatory zoning in plagioclase is commonly interpreted as being a result of kinetically or diffusion-controlled growth (Bottinga et al 1966; Pearce and Kolisnik 1990), decompression (Nelson and Montana 1992), and magma convection (e.g., Singer et al. 1995).

The chemical compositions of the pargasite and magnesiohastingsite $\left(\mathrm{X}_{\mathrm{Mg}} 0.51-0.86\right)$ are consistent with amphibole from typical andesite and basaltic andesite (Moore and Carmichael 1998; Grove et al. 2003, 2005). The amphibole phenocrysts are typically oscillatoryzoned with slight oscillations in Si (5.78-6.55 apfu) and in Al (1.59-2.64 apfu) contents. The same phenocrysts from trachybasalt and trachyandesite contain partially resorbed cores, rimmed by amphibole with high $\mathrm{X}_{\mathrm{Mg}}$ (0.79-0.84) and Al (2.36-2.40 apfu) contents. The resorption surfaces may record convection and/or influx of hot, mafic melt into the magma chamber (e.g., Singer et al. 1995; Ginibre et al. 2002; Humphreys et al. 2006). The small variation in amphibole composition in some samples reflects the relatively limited changes in $\mathrm{fO}_{2}$ and melt composition, including $\mathrm{H}_{2} \mathrm{O}$ content (e.g., Luhr and Carmichael 1980; Scaillet and Evans 1999; Bachmann and Dungan 2002; Rooney et al. 2010). Systematic changes in $\mathrm{Si}, \mathrm{Ti}$, ${ }^{\mathrm{VI}} \mathrm{Al}, \mathrm{X}_{\mathrm{Mg}}$ contents in amphiboles from trachydacites and gabbro enclaves can be explained by fractional crystallization. Based on textural features and calculated $\mathrm{T}, \mathrm{P}, \mathrm{fO}_{2}$ and $\mathrm{H}_{2} \mathrm{O}$ contents in the melt (Ridolfi et al. 2010), we interpret normal and oscillatory zoning of the amphibole phenocrysts as being a result of gradual cooling during fractional crystallization.

The felsic rocks of the Bučník laccolith define a chemically coherent group of trachyandesites to trachydacites that can be related to the fractional crystallization model. Systematic variations in whole-rock $\mathrm{FeO}_{t}, \mathrm{TiO}_{2}$, $\mathrm{K}_{2} \mathrm{O}, \mathrm{CaO}$, and $\mathrm{Rb}$ with increasing $\mathrm{SiO}_{2}$ content (Figs $5 \mathrm{~d}, 6)$ imply fractionation of amphibole, clinopyroxene, plagioclase, and/or Fe-Ti oxides.

The complex evolution of some major and trace elements (Figs 6 and $7 \mathrm{a}-\mathrm{b}$; e.g., $\mathrm{Al}_{2} \mathrm{O}_{3}, \mathrm{Rb}, \mathrm{Sr}$, and $\mathrm{Ba}$ ) corresponding to increasing contents from basalt through trachybasalt to trachyandesite and subsequent decrease to trachydacite can probably be interpreted as being a result of the onset of fractionation of K-feldspar and biotite, simultaneously with continued crystallization of amphibole and plagioclase, at the final stage of magma evolution. During fractional crystallization, the $\mathrm{La} / \mathrm{Yb}$ ratio progressively increases (Fig. 7d) because amphibole preferentially incorporates MREE and HREE over LREE. Accessory minerals may also be important. Nejbert et al. (2012) described the presence of chevkinite, zirconolite, monazite-(Ce) and $\mathrm{Nb}$-rich ilmenite that crystallized contemporaneously with K-feldspar.

The gabbro enclaves have similar mineralogy to the surrounding trachydacite or trachyandesite. Textural evidence shows that the minor diopside and olivine (pseudomorphosed by calcite) crystallized earlier than the amphiboles. Pargasitic amphibole and clinopyroxene are interpreted as cumulus and fine-grained calcic plagioclase as intercumulus. Diopside is characterized by simple zoning with $\mathrm{Mg}\left(\mathrm{X}_{\mathrm{Mg}} 0.67-0.79\right)$ and its core has similar composition to phenocrysts from the trachybasalt (Tab. 1). The negative correlation between $\mathrm{Mg}$ and $\mathrm{Ti}$ (Fig. 3b) in diopsides from gabbro enclaves and trachydacite can be explained by decompression during fractional crystallization (e.g., Tracy and Robinson 1977; Rapprich et al. 2017). The amphibole compositional trends for leucocratic and melanocratic gabbro enclaves are similar to those for the amphibole from the host-rock (trachydacite, Fig 3d). The rimward Ti enrichment in amphibole (Fig. 3f) can be explained by fractional crystallization (e.g., Tiepolo et al 2011). On the other hand, textural 


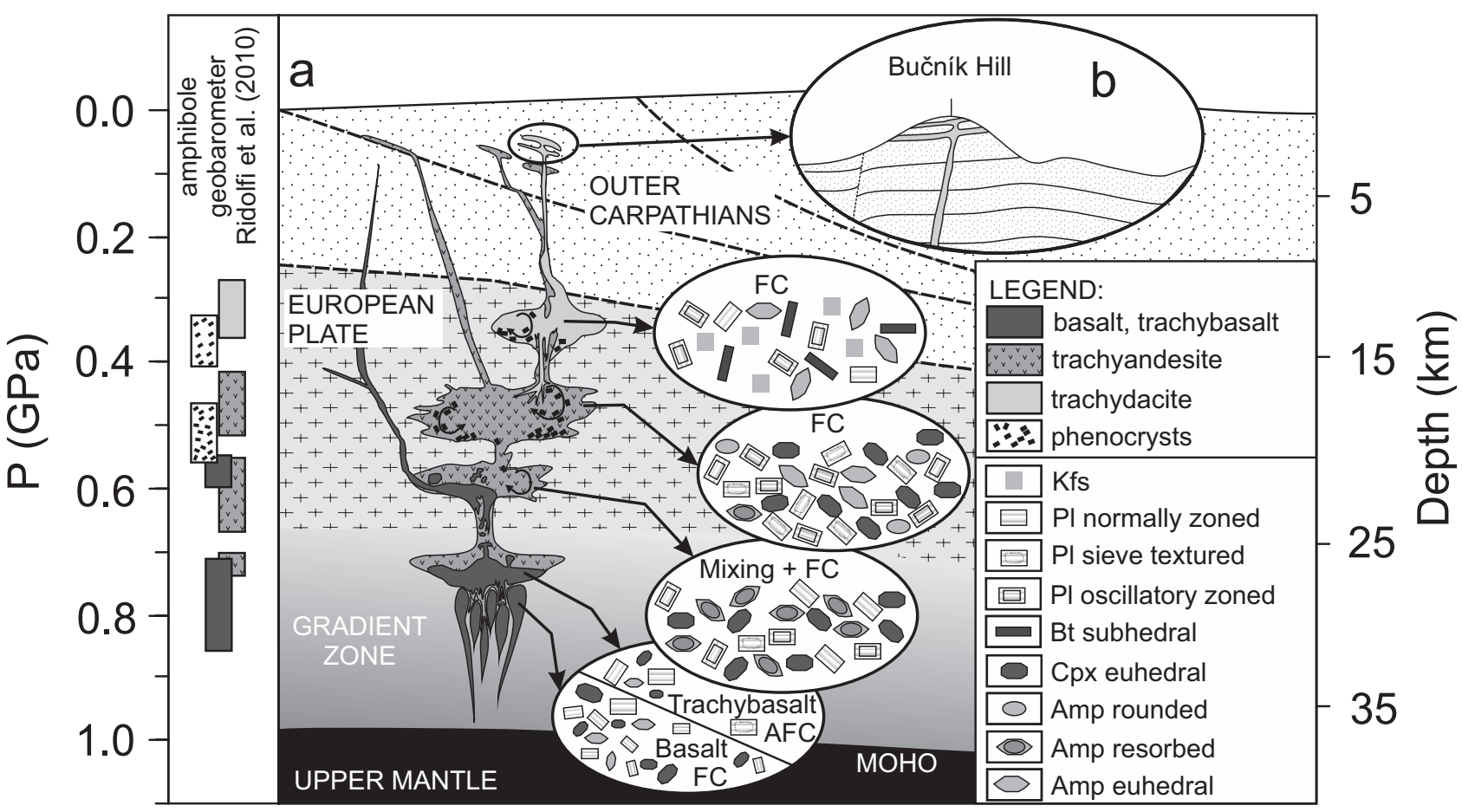

Fig. 9 Schematic diagram showing range of pressures for individual amphibole populations from studied rocks calculated by the geobarometer Ridolfi et al. (2010), and summarizing their assumed mode of formation. Cross-section through crust (a) created according to the geophysical model of Hrubcová et al. (2005). Insert figure (b) shows a model of the Bučník cedar-tree laccolith after Blížkovský (1986). AFC = fractional crystallization and crustal assimilation of mantle-derived basaltic magmas, $\mathrm{FC}=$ closed-system fractional crystallization, Mixing = magma mixing and mingling.

evidence (the presence of clinopyroxene inclusions in the amphibole phenocrysts) indicates that at least a portion of the amphibole formed through a peritectic reaction consuming clinopyroxene. The absence of significant compositional differences between the small grains and large amphibole phenocrysts likely precludes multiple generations of crystals.

Chemical compositions of the subvolcanic rocks as well as the presence of gabbro enclaves indicate an important role of magmatic fractionation. The gabbro enclaves are interpreted to represent disrupted fragments of cumulate from the magma chamber at a depth of c. $14-20 \mathrm{~km}$. The formation of amphibole-rich cumulates as the result of fractional crystallization clearly explains the transition from trachyandesites to trachydacites.

\subsection{Magma ascent and emplacement}

Based on the CEL09 profile modeled by Hrubcová et al. (2005), we assume that the Western Outer Carpathian region was formed in Miocene times by $>5 \mathrm{~km}$ thick sedimentary sequences of the Carpathian nappes and Paleozoic sediments (Fig. 9). Cadomian metamorphic and igneous rocks built a basement which gradually passed to the lower crustal composition. These changes probably involved an increase in the metamorphic grade with incomplete phase transition of the mafic (gabbroic) rocks from amphibolite to the eclogite facies (Hrubcová et al. 2005).

The amphibole thermobarometry after Ridolfi et al. (2010) is suitable for the calculation of pre-eruptive conditions of calc-alkaline magmas including upper to middle continental crustal settings. Ridolfi and Renzulli (2012) revised the previous calibrations and presented new empirical equations for calcic amphiboles in calcalkaline and alkaline magmas (mainly for intraplate and complex geodynamic settings). Table 1 and figures in ESM 4 show that the results for both calibrations are similar, but thermobarometric results using Ridolfi et al. (2010) overlap with those based on amphibole-liquid (Putirka 2016) and plagioclase-liquid (Putirka 2005, 2008) equilibria.

We have calculated amphibole crystallization $\mathrm{P}-\mathrm{T}-\mathrm{X}$ conditions with several equations based on chemical composition amphibole and elements partitioning between amphibole, plagioclase and/or melt. Individual equations provide slightly different ranges in $\mathrm{P}-\mathrm{T}-\mathrm{X}$ conditions (Tab. 1). Partitioning between amphibole and other phases in magmatic rocks is still poorly understood (Putirka 2016). Based on concerns raised by Erdmann et al. (2014) and Putirka (2016) we correlated observed mineral assemblages of trachyandesites and trachybasalts with those produced in crystallization experiments with the following results: 
(I) Trachyandesite, trachybasalt and basalt crystallization temperatures calculated using the Ridolfi et al. (2010) calibration seem realistic, even though slightly higher than those obtained from other thermometers (Tab. 1, ESM 4a, c). For example, according to the experimental results of Grove et al. (2003), amphibole in basaltic andesite crystallized at a pressure of $0.8 \mathrm{GPa}$ and temperature of $1045^{\circ} \mathrm{C}\left(\sim 14\right.$ wt. $\left.\% \mathrm{H}_{2} \mathrm{O}\right)$, whereas at 0.2 $\mathrm{GPa}$, the temperature of crystallization was $990^{\circ} \mathrm{C}(\sim 6$ wt. $\% \mathrm{H}_{2} \mathrm{O}$ ).

(II) There is good positive correlation between pressures calculated using the Ridolfi et al. (2010) calibration and the amphibole-liquid barometer of Putirka (2016) as well as experimental data (Tab. 1, Fig. 8a, figures in ESM 4d).

(III) Stability of amphibole in andesitic and basaltic melt is mainly a function of melt $\mathrm{H}_{2} \mathrm{O}$ content and pressure (Andújar et al. 2016, 2015). Experimental data indicate that in andesitic (at $0.2-0.4 \mathrm{GPa}$ and $920^{\circ} \mathrm{C}$ ) and basaltic (at $\sim 0.2-0.4 \mathrm{GPa}, 975^{\circ} \mathrm{C}$ ) melts, amphibole stability is limited to $\sim 6.5-9.1$ wt. $\% \mathrm{H}_{2} \mathrm{O}$ at $\mathrm{fO}_{2}-12$ to -11 (Andújar et al. 2016) and $~ 4.6-8.9$ wt. $\% \mathrm{H}_{2} \mathrm{O}$ at $\mathrm{fO}_{2}$ -12 to -10 (Andújar et al. 2015), respectively. However, calculated melt $\mathrm{H}_{2} \mathrm{O}$ contents for trachyandesites, trachybasalts and basalts crystallization using the Ridolfi et al. (2010) calibration are often outside the amphibole stability field (Fig. 8c). This is in agreement with concerns that calculated melt $\mathrm{H}_{2} \mathrm{O}$ contents in the volcanic systems are often unrealistic and can reflect compositional variation of the crystallizing magmas and crystallization temperature (Erdmann et al. 2014).

(IV) Calculated $\mathrm{fO}_{2}$ values using the Ridolfi et al. (2010) calibration vary between $\triangle \mathrm{NNO}-1.1$ and $\Delta \mathrm{NNO}$ +1.2 and correlate well with most experimental values (Fig. 8b).

Based on overlap with experimental results, we conclude that the thermobarometric calculations based on Ridolfi et al. (2010) formulations are realistic (Tab. 1). However some calculated contents of $\mathrm{H}_{2} \mathrm{O}$ in melt are outside the known experimental stability field of amphibole.

The $\mathrm{P}-\mathrm{T}$ values obtained by amphibole thermobarometry (Ridolfi et al. 2010) from the studied subvolcanic rocks indicate crystallization of the amphibole phenocrysts at different crustal levels (Tab. 1). The amphibole phenocrysts from the basalt enclave grew at a deep crustal level $(\sim 27-32 \mathrm{~km})$. The pargasites from the surrounding trachyandesites are chemically less homogenous and record a relatively wide range of $\mathrm{P}-\mathrm{T}$ conditions (Tab. 1). They can be subdivided into two groups. The cores $\left(\mathrm{T}=1035-1055^{\circ} \mathrm{C} ; \mathrm{P}=0.71-0.74 \mathrm{GPa}\right)$ of some amphibole phenocrysts indicate similar $\mathrm{P}-\mathrm{T}$ conditions (1045-1058 ${ }^{\circ} \mathrm{C}$ and $\left.0.71-0.86 \mathrm{GPa}\right)$ to the basalt enclave. On the other hand, the $\mathrm{P}-\mathrm{T}$ conditions calculated for the rims of the amphibole phenocrysts and for the small grains in the groundmass yield significantly lower $\mathrm{P}-\mathrm{T}$ conditions $\left(\mathrm{T}=975-1037^{\circ} \mathrm{C} ; \mathrm{P}=0.42-0.67 \mathrm{GPa}\right)$. Hence the cores of the amphibole phenocrysts crystallized at depths of $27-28 \mathrm{~km}$, while the rims were formed at $16-25$ $\mathrm{km}$. Oscillations in the $\mathrm{P}-\mathrm{T}$ conditions calculated for the individual zones of the amphibole phenocrysts, together with the presence of resorption zones, indicate convection movements in the magma chamber. Convection also probably caused resorption of previously crystallized zones of amphibole during stirring of the magma in the magma chamber. The predominant part of the amphibole phenocrysts from trachybasalt and trachyandesite comprises oscillation zones which can be interpreted as the product of crystallization at a depth of $21-25 \mathrm{~km}$.

The variability in the chemical compositions of the trachybasalt and trachyandesite as well as disequilibrium textures in the plagioclase phenocrysts (sieved cores) indicate magma mingling and mixing (Stimac and Pearce 1992; Venezky and Rutherford 1997) in a deep-crustal magma chamber $(21-23 \mathrm{~km})$.

The general trends in the chemical compositions of trachydacites suggest predominant control by fractional crystallization, which would lead to decreasing $\mathrm{mg} \#$ value due to fractionation of the Mg-rich phases. Trachyandesite magmas rose in the shallow crust into the magma reservoirs at a depth of $\sim 8-14 \mathrm{~km}$ and underwent fractional crystallization to form trachydacites (the fractionation trends in Fig. 7c-d). The estimated P-T conditions for crystallization of the cumulate gabbro enclaves are $936-1023^{\circ} \mathrm{C}$ and $\mathrm{P}=0.33-0.56 \mathrm{GPa}$ and thus similar to the $\mathrm{P}-\mathrm{T}$ conditions calculated for crystallization of amphibole phenocrysts from trachydacite and trachyandesite (Tab. 1). Fractional crystallization and crustal contamination at deep crustal levels produced hydrous magmas that partly lost volatiles during ascent due to exsolution of magmatic fluids as a result of decompression driven by opening of the magmatic system. This concept is supported by the highly variable $\mathrm{H}_{2} \mathrm{O}(4.4-6.6$ wt. \%) abundances in the trachyandesitic and trachydacitic melts.

The studied subvolcanic rocks form predominantly dykes, sills and laccoliths, which intruded into a cold, near-surface environment. The vitrinite reflection index from the surrounding sediments (outside the contact aureole) indicated maximum burial depths of $c .1 .5-2.0 \mathrm{~km}$ $\left(\mathrm{T}_{\max }=432-444^{\circ} \mathrm{C}\right.$; Bíl et al. 2004).

\subsection{Alteration}

Studied subvolcanic rocks were affected to a variable degree by secondary hydrothermal alteration. Two types of fluids were distinguished based on investigation of the fluid inclusions of hydrothermal mineralisation hosted by trachyandesites from this site: low-salinity $\mathrm{H}_{2} \mathrm{O}-\mathrm{NaCl} \pm$ 
$\mathrm{KCl} \pm \mathrm{MgCl}_{2}$ fluids and medium- to high-salinity $\mathrm{H}_{2} \mathrm{O}$ $\mathrm{NaCl}-\mathrm{CaCl}_{2}$ fluids (Ulmanová 2015). The volcanic glass as well as primary igneous minerals are typically altered to mixtures of sericite, chlorite and calcite. Total loss on ignition (LOI) may be a good indicator of secondary alteration. Rocks with higher LOI (4.3-7.5 wt. \%) contain altered glass (3-10 vol. \%). In contrast, most of the rock samples from the Bučník quarry near Komňa exhibit relatively low LOI contents (1.5-3.2 wt. \%) but were affected by late postmagmatic alteration (albitization, silicification, and K-metasomatism). Postmagmatic hydrothermal processes can be responsible for the modified contents of $\mathrm{Na}$, MREE, LILE (for example Ba and Sr; Fig 7e) and HREE (Fig. 7a-b), but did not significantly influence the contents of Th, Zr, Hf, LREE (e.g., Helvaci and Griffin 1983; Pandarinach et al. 2008; Salaün et al. 2011). The low variation in the U/Th $(0.2-0.3), \mathrm{La} / \mathrm{Th}(3.1-6.1)$, $\mathrm{Rb} / \mathrm{Nb}(1.0-4.7)$ and $\mathrm{Nb} / \mathrm{Y}(1.4-9.9)$ ratios indicate that hydrothermal alteration did not play a fundamental role in the formation of trachydacite (Pandarinach et al. 2008; Salaün et al. 2011).

\section{Conclusions}

The post-tectonic complex of small laccoliths and dykes of high-K calc-alkaline subvolcanic rocks situated near Uherský Brod in southeastern Moravia (Czech Republic) consists of (clinopyroxene-)amphibole trachybasalts, trachyandesites, and biotite-amphibole trachydacites. These subvolcanic rocks rarely contain leucocratic to melanocratic cumulate gabbro and basalt enclaves up to $70 \mathrm{~cm}$ in diameter. Their petrographical and geochemical variability suggests a complicated evolution at several crustal levels.

Mafic mineral compositional variability is limited. The diopside phenocrysts show narrow ranges of $\mathrm{X}_{\mathrm{Mg}}$ $0.65-0.84$ and usually display normal zoning with small $\mathrm{Mg}$-rich cores and Fe-rich rims. Phlogopites from the trachydacite and gabbro enclaves have mutually similar compositions ( $\mathrm{X}_{\mathrm{Fe}} 0.36-0.43$ and $\left.{ }^{\mathrm{IV}} \mathrm{Al} 2.44-2.59\right)$. The amphiboles (pargasite, magnesiohastingsite and tschermakite) from individual samples of basalt, trachybasalt and trachyandesite are chemically relatively homogeneous $\left(\mathrm{X}_{\mathrm{Mg}}\right.$ 0.51-0.86, Si 5.78-6.55). Systematic changes in $\mathrm{Si}, \mathrm{Ti}$, ${ }^{\mathrm{V}} \mathrm{Al}, \mathrm{X}_{\mathrm{Mg}}$ contents in amphiboles from trachydacites and gabbro enclaves can be explained by fractional crystallization.

Amphibole thermobarometry showed that mantlederived basaltic magma ascended through the lithosphere and interacted with the crust at a depth of $\sim 27-32 \mathrm{~km}$ and a temperature of $\sim 1050$ to $1060^{\circ} \mathrm{C}$. This interaction resulted in partial melting of the crust and formation of trachybasalt and trachyandesite magmas. Relatively high abundances of trace elements such as $\mathrm{Sr}, \mathrm{Ba}$ and $\mathrm{Zr}$ suggest a possible role for crustal contamination in the genesis of the trachybasalts.

Trachyandesite magmas rose into magma reservoirs at $\sim 21-25 \mathrm{~km}\left(\mathrm{~T}=975\right.$ to $1055^{\circ} \mathrm{C}$ and $\mathrm{P}=0.42$ to 0.74 $\mathrm{GPa}$ ) and underwent fractional crystallization combined with magma mingling and mixing with the trachybasalt melt (the $\mathrm{P}-\mathrm{T}$ conditions calculated for amphibole phenocrysts in trachybasalt range $\sim 1030-1040^{\circ} \mathrm{C}$ and $0.55-0.60 \mathrm{GPa}$ ).

The residual trachydacitic melt produced by fractional crystallization of the trachyandesite rose into a shallower still magma reservoir $(\sim 10-13 \mathrm{~km})$. The amphibole composition from trachydacites yielded crystallizing temperatures of $928-962^{\circ} \mathrm{C}$ and pressures of 0.27 to $0.37 \mathrm{GPa}$. Gabbro enclaves in the trachydacite are also derived from upper crustal reservoirs where they crystallized under similar conditions as trachyandesite and trachydacite. The gabbro enclaves are interpreted to represent disrupted fragments of cumulate from the magma chamber at depth of approximately $\sim 14-20 \mathrm{~km}$.

Taken together, the thermobarometric data illustrate that the parental magmas of trachybasalts and trachyandesites were initially emplaced at the mid-crustal level, where they underwent fractional crystallization combined with magma mingling and mixing, whereas trachydacites are interpreted as a product of upper crustal closedsystem fractional crystallization.

Acknowledgements. The authors wish to thank Michaela Hašková for helping with fieldwork and Madeleine Štulíková for revision of the English in the manuscript. We are also grateful to Jaromír Ulrych and an anonymous reviewer for constructive criticism that significantly improved the manuscript. We certainly wish to thank the handling editor, John M. Hora and the editor-in-chief, Vojtěch Janoušek, for general notes to the manuscript. This work was supported by the Czech Geological Survey research project No. 321180 (to D.B.) and project IGA_PrF_2018_025 (to K.K.).

Electronic supplementary material. Supplementary tables of chemical compositions with recalculated crystal-formulae of amphiboles, feldspars and clinopyroxenes as well as a figure comparing crystallization temperatures and pressures estimated by different methods, are available online at the Journal web site (http://dx.doi.org/10.3190/jgeosci.286).

\section{References}

ANCZKIEWICZ AA, ANCZKIEWICZ R (2016) U-Pb zircon geochronology and anomalous $\mathrm{Sr}-\mathrm{Nd}-\mathrm{Hf}$ isotope systematics 
of late orogenic andesites: Pieniny Klippen Belt, Western Carpathians, South Poland. Chem Geol 427: 1-16

Andújar J, Scaillet B, Pichavant M, Druitt TH (2015) Differentiation conditions of a basaltic magma from Santorini, and its bearing on the production of andesite in arc settings. J Petrol 56: 765-794

Andújar J, Scaillet B, Pichavant M, Druitt TH (2016) Generation conditions of dacite and rhyodacite via the crystallization of an andesitic magma. Implications for the plumbing system at Santorini (Greece) and the origin of tholeiitic or calc-alkaline differentiation trends in arc magmas. J Petrol 57: 1887-1920

Bachmann O, Dungan MA (2002) Temperature-induced Al-zoning in hornblendes of the Fish Canyon magma, Colorado. Amer Miner 87: 1062-1076

Bíl M, Krejčí O, Francủ J, Hrouda F, Přichystal A (2004) Estimation of the missing eroded sediments in the Bílé Karpaty Unit (Outer West Carpathians). Stud Geomorph Carpatho-Balcan 38: 59-66

BLÍŽKovsKÝ V (1986) Evaluation of Mining of Hg Indices in Komňa. Unpublished MSci Thesis, Jan Evangelista Purkyně University, Brno, pp 1-58 (in Czech)

Bottinga Y, Kudo AM, Weill D (1966) Some observations on oscillatory zoning and crystallization of magmatic plagioclase. Amer Miner 51: 792-806

Boynton WV (1984) Cosmochemistry of the rare earth elements: meteorite studies. In: HENDERSON P (ed) Rare Earth Element Geochemistry. Elsevier, Amsterdam, pp 63-114

CoRnejo P, MAHOOD G (1997) Seeing past the effects of re-equilibration to reconstruct magmatic gradients in plutons: La Gloria Pluton, central Chilean Andes. Contrib Mineral Petrol 127: 159-175

Couch S, Harford CL, Sparks RSJ, Carroll MR (2003) Experimental constraints on the conditions of formation of highly calcic plagioclase microlites at the Soufrière Hills Volcano, Montserrat. J Petrol 44: 1455-1475

ČERNÝ P (1958) Propylitic ore veins and their minerals from Komňa near Bojkovice. Geol Sbor Slov Akad Vied 9: 300-323 (in Czech)

Doвosi G, Fodor FV (1992) Magma fractionation, replenishment, and mixing as inferred from green core clinopyroxenes in Pliocene basanite, Southern Slovakia. Lithos 28: 133-150

DROOP GTR (1987) A general equation for estimating $\mathrm{Fe}^{3+}$ in ferromagnesian silicates and oxides from microprobe analysis, using stoichiometric criteria. Mineral Mag 51: 431-437

EICHELBERGER JC (1975) Origin of andesite and dacite: evidence of mixing at Glass Mountain in California and at other circum-Pacific volcanoes. Geol Soc Am Bull 86: 1381-1391

Erdmann S, Martel C, Pichavant M, Kushnir A (2014) Amphibole as an archivist of magmatic crystallization conditions: problems, potential, and implications for inferring magma storage prior to the paroxysmal 2010 eruption of Mount Merapi, Indonesia. Contrib Mineral Petrol 167: 1-23

Ersoy Y, Helvaci C (2010) FC-AFC-FCA and mixing modeler: a Microsoft ${ }^{\circledR}$ Excel $^{\odot}$ spreadsheet program for modeling geochemical differentiation of magma by crystal fractionation, crustal assimilation and mixing. Comput Geosci 36: 383-90

FEDIUK F, GüRTLEROvá P (2006) Adakitic trends in andesitic volcanics of SE-Moravia. Bull mineral-petrol odd Nár Muz 13: 121-124 (in Czech)

Fodor L, Csontos L, Bada G, Gyorfy I, Benkovics L (1999) Tertiary tectonic evolution of the Pannonian Basin system and neighboring orogens: a new synthesis of paleostress data. In: Durand B, Jolivert L, Horvath F, SERANNe M (eds) The Mediterranean Basins: Tertiary Extensions Within the Alpine Orogen. Geological Society of London Special Publications 156: 295-334

FoJT B, P̌̌IChYSTAL A (1979) Sphalerite and carbonate from ore veins in propylitised andesite from Komňa (southeastern Moravia). Scr Fac Sci Nat Univ J E Purkyně, Brunensis, Geol 1: 17-28 (in Czech)

GHIORso MS, Evans BW (2008) Thermodynamics of rhombohedral oxide solid solutions and a revision of the $\mathrm{Fe}-\mathrm{Ti}$ two-oxide geothermometer and oxygen-barometer. Amer J Sci 308: 957-1039

Ginibre C, Wörner G, Kronz A (2002) Minor and trace elements zoning in plagioclase: implications for magma chamber processes at Parinacota Volcano, northern Chile. Contrib Mineral Petrol 143: 300-315

Grove TL, Elkins-Tanton LT, Parman SW, Chatterjee N, MÜNTENER O, GAETANI GA (2003) Fractional crystallization and mantle-melting controls on calc-alkaline differentiation trends. Contrib Mineral Petrol 145: 515-533

Grove TL, Baker MB, Price RC, Parman SW, ElkinsTanton LT, Chatterjee N, Müntener O (2005) Magnesian andesite and dacite flows from Mt. Shasta, northern California: products of fractional crystallization of $\mathrm{H}_{2} \mathrm{O}$-rich mantle melts. Contrib Mineral Petrol 148: $542-565$

HARANGI S (2001) Neogene to Quaternary volcanism of the Carpathian-Pannonian region - a review. Acta Geol Hungarica 44: 223-258

Harangi S, Downes H, Kósa L, Szabó C, Thirlwall MF, MASON PRD, MatTEY D (2001) Almandine garnet in calc-alkaline volcanic rocks of the Northern Pannonian Basin (Eastern-Central Europe): geochemistry, petrogenesis and geodynamic implications. J Petrol 42: 1813-1843

Harangi S, Downes H, Thirlwall M, Gméling K (2007) Geochemistry, petrogenesis and geodynamic relationships of Miocene calc-alkaline volcanic rocks in the Western Carpathian arc, eastern central Europe. J Petrol 48: 2261-2287 
Hastie AR, Kerr AC, Pearce JA, Mitchell SF (2007) Classification of altered volcanic island arc rocks using immobile trace elements: development of the Th-Co discrimination diagram. J Petrol 48: 2341-2357

HAŠKová M (2018) Xenoliths of Igneous Rocks in Trachyandesites from the Quarry Bučník near the Komňa Village. Unpublished BSci Thesis, Palacký University, Olomouc, pp 1-50

HeLVACI C, GrifFIN WL (1983) Metamorphic feldspathization of metavolcanics and granitoids, Avnik area, Turkey. Contrib Mineral Petrol 83: 309-319

Holland T, BLundy J (1994) Non-ideal interactions in calcic amphiboles and their bearing on amphibole-plagioclase thermometry. Contrib Mineral Petrol 116: 433-447

Hrouda F, Buriánek D, KrejČí O, Chadima M (2015) Magnetic fabric and petrology of Miocene sub-volcanic sills and dykes emplaced into the SW Flysch Belt of the West Carpathians (S Moravia, Czech Republic) and their volcanological and tectonic implications. J Volcanol Geotherm Res 290: 23-38

Hrubcová P, Środa P, Špičćk A, Guterch A, Grad M, Keller GR, BrüCKL E, Thybo H (2005) Crustal and uppermost mantle structure of the Bohemian Massif based on CELEBRATION 2000 data. J Geophys Res 110: B11305

Humphreys MCS, Blundy JD, Sparks RSJ (2006) Magma evolution and open system processes at Shiveluch Volcano: insights from phenocrysts zoning. J Petrol 47: 2303-2334

IRVINE TN, BARAGAR WRA (1971) A guide to the chemical classification of the common volcanic rocks. Canad J Earth Sci 8: 523-548

JANOUŠEK V, FARROW CM, ERBAN V (2006) Interpretation of whole-rock geochemical data in igneous geochemistry: introducing Geochemical Data Toolkit (GCDkit). J Petrol 47: 1255-1259

JoHNSON MC, RUTHERFoRd MJ (1989) Experimental calibration of the aluminum-in hornblende geobarometer with application to Long Valley Caldera (California) volcanic rocks. Geology 17: 837-841

Jolivet L, Frizon de Lamotte D, Mascale A, Séranne M (1999) The Mediterranean Basins: Tertiary extension within the Alpine Orogen - an introduction. In: DURAND B, Jolivet L, Horváth F, SÉranne M (eds) The Mediterranean Basins: Tertiary Extension Within the Alpine Orogen. Geological Society of London Special Publications 156: 1-14

KoneČnÝ V, Kováč M, LeXa J, Šefara J (2002) Neogene evolution of the Carpatho-Pannonian region: an interplay of subduction and back-arc diapiric uprise in the mantle. EGU Stephan Mueller Special Publication Series 1 (2002): 105-123

Kováč M, Nogymarossy A, Oszczypko N, Šlączka A, Csontos L, Mărunţeanu M, Maţenco L, Márton
M (1998) Palinspastic reconstruction of the Carpathian-Pannonian region during the Miocene. In: RaKus M (ed) Geologic Development of the Western Carpathians. Geological Survey of Slovak Republic, Bratislava, pp 189-217

Krejčí O, Adamová M, Rybařová L, Pálenský P, Peslová H, Švábenická L, Bubík M, STRnad M, Eliáš M, Mokřovská V, Č́ekan V, P̌̌ichystal A, HavlíčeK P (1990) Basic geologic map and explanations to basic geologic map 1:25 000, sheet 35-121 Bánov. Czech Geological Survey, Prague (in Czech)

KRETZ R (1983) Symbols of rock-forming minerals. Amer Miner 68: 277-279

KRYSTEK I (1955) Alkaline igneous rocks in southeastern Moravia. Geol Práce 41: 103-130 (in Czech)

KRYSTEK I (1958) Xenoliths of alkaline igneous rocks in southeastern Moravia. Věst Ústř Úst Geol 33: 246-252 (in Czech)

Kucharič L, BezÁk V, Kubeš P, KonečnÝ V, VozÁr J (2013) New magnetic anomalies in the NE Slovakia and their relationship to the Carpathian Conductivity Zone. Geol Q 57: 123-134

Laeger K, Halama R, Hansteen T, Savov IP, Murcia H, CORTÉs G, GARBE-SCHÖNBERG D (2013) Crystallization conditions and petrogenesis of the lava dome from the 900 years BP eruption of Cerro Machín Volcano, Colombia. J South Am Earth Sci 48: 193-208

Le Bas MJ, Le Maitre R W, Streckeisen, A, Zanettin B (1986) A chemical classification of volcanic rocks based on the total alkali-silica diagram. J Petrol 27: 745-750

Le Maitre RW, Streckeisen A, Zanettin B, Le Bas MJ, Bonin B, Bateman P, Bellieni G, Dudek A, Efremova S, Keller J, Lameyre J, Sabine PA, Schmid R, Sorensen H, Woolley AR (2002) Igneous Rocks: A Classification and Glossary of Terms, Recommendations of the International Union of Geological Sciences, Subcommission of the Systematics of Igneous Rocks. Cambridge University Press, Cambridge, pp 1-236

Leake BE, Wooley AR, Arps CES, Birch WD, Gilbert MC, Grice JD, Hawthorne FC, Kato A, Kisch HJ, Krivovichev VG, Linthout K, Laird J, Mandarino J, Maresch WV, Nickel EH, Rock NMS, Schumacher JC, Smith JC, Stephenson NCN, Whittaker EJW, YouZHI G (1997) Nomenclature of amphiboles: report of the Subcommittee on Amphiboles of the International Mineralogical Association Commission on New Minerals and Mineral Names. Canad Mineral 35: 219-237

LeXa J, KoneČnÝ V (1999) Geodynamic aspects of the Neogene to Quaternary volcanism. In: RAKUS M (ed) Geologic Development of the Western Carpathians. Geological Survey of Slovak Republic, Bratislava, pp 219-240

LeXa J, KoneČnÝ V, Kováč M, NemčoK M (1995) Relationship among convergence, back-arc extension and 
volcanism in the Western Carpathians during Neogene. Europrobe-Pancardi Workshop, Stará Lesná, Abstracts. Geological Institute, Slovak Academy of Sciences, Bratislava, pp 65

Lexa J, Seghedi I, Németh K, Szakács A, KonečnÝ V, PÉCSKAY Z, FÜLÖP A, KovaCS M (2010) Neogene-Quaternary volcanic forms in the Carpathian-Pannonian region: a review. Cent Eur J Geosci 2: 207-270

Luhr JF, CARMichael ISE (1980) The Colima volcanic complex, Mexico: I. Post-caldera andesites from volcano Colima. Contrib Mineral Petrol 71: 343-372

Molina JF, Moreno JA, Castro A, Rodríguez C, FerSHTATER GB (2015) Calcic amphibole thermobarometry in metamorphic and igneous rocks: new calibrations based on plagioclase/amphibole Al-Si partitioning and amphibole/liquid Mg partitioning. Lithos 232: 286-305

Moore G, Carmichael ISE (1998) The hydrous phase equilibria (to $3 \mathrm{kbar}$ ) of an andesite and basaltic andesite from western Mexico: constraints on water content and conditions of phenocryst growth. Contrib Mineral Petrol 130: 304-319

Morimoto N, Fabries J, Ferguson AK, Ginzburg IV, Ross M, Seifert FA, Zussman J, Aoki K, Gottardi G (1988) Nomenclature of pyroxenes. Amer Miner 73: 1123-1133

NaKamura M, Shimakita S (1998) Dissolution origin and syn-emplacement compositional change of melt inclusion in plagioclase. Earth Planet Sci Lett 161: 119-133

Nejbert K, Jurewicz E, Macdonald R (2012) Potassiumrich magmatism in the Western Outer Carpathians: magmagenesis in the transitional zone between the European Plate and Carpathian-Pannonian region. Lithos 146-147: 34-47

Nelson ST, Montana A (1992) Sieve-textured plagioclase in volcanic rocks produced by rapid decompression. Amer Miner 77: 1242-1249

NemČok M, Pospisil L, Lexa J, Donelik RA (1998) Tertiary subduction and slab breakoff model of the CarpathianPannonian region. Tectonophysics 295: 307-340

Nixon GT (1988) Petrology of the younger andesites and dacites of Iztaccihuatl Volcano, Mexico: disequilibrium phenocryst assemblages as indicators of magma chamber processes. J Petrol 29: 213-264

ORTOLEVA P (1990) The role of attachment kinetic in oscillatory zoning crystals growth from melt. Earth Sci Rev 29: 3-8

Pandarinach K, Dulski P, Torres-Alvarado IS, Verma SP (2008) Element mobility during hydrothermal alteration of rhyolitic rocks of the Los Azufres geothermal field, Mexico. Geothermics 37: 53-72

Pearce TH, Kolisnik AM (1990) Observations of plagioclase zoning using interference imaging. Earth Sci Rev 29: 9-26

Peccerillo A, TaYlor SR (1976) Geochemistry of Eocene calc-alkaline volcanic rocks from the Kastamonu area, northern Turkey. Contrib Mineral Petrol 58: 63-81
Pécskay Z, Lexa J, Szakács A, Balogh K, Seghedi I, KoneČnÝ V, Kovacs M, MÁRTon E, SzÉKy-Fux V, PóKA T, Gyarmaty P, Edelstein O, Roşu E, Žec B (1995) Space and time distribution of Neogene-Quaternary volcanism in the Carpatho-Pannonian region. Acta Vulcanol 7: 15-29

Pécskay Z, Lexa J, Szakács A, Seghedi I, Balogh K, KonečnÝ V, Zelenka T, Kovacs M, Póka T, FülöP A, Márton E, Panaiotu C, Cvetković V (2006) Geochronology of Neogene-Quaternary magmatism in the Carpathian arc and Intra-Carpathian area: a review. Geol Carpath 57: 511-530

PÉCSKay Z, GMéling K, LeXa J, KoneČNÝ V, BiRKenMaJer K (2008) Comparison and connection between Neogene andesite intrusions following the calc-alkaline arc in the West Carpathians. IAVCEI-CVS-IAS 3IMC Conference. Malargüe, Argentina, pp 91-92

Pouchou JL, PichOIR F (1985) "PAP“" $(\varphi-\rho-z)$ procedure for improved quantitative microanalysis. In: ARMSTRONG JT (ed) Microbeam Analysis. San Francisco Press, San Francisco, pp 104-106

PřIChYSTAL A (1974) Mineralogical-Chemical Study of Mineral Associations from Bučník (Komňa u Bojkovice). Unpublished MSci. Thesis, Jan Evangelista Purkyně University, Brno, pp 1-93 (in Czech)

PŘıchystal A (1993) Paleozoic to Quaternary volcanism in the geological history of Moravia and Silesia. In: Přichystal A, Obstová V, Suk M (eds) Geologie Moravy a Slezska: Sborník př́spěvků k 90. výročí narození prof. Dr. Karla Zapletala. Moravian Museum and Department of Geological Sciences, Faculty of Science, Masaryk University, Brno, pp 59-70 (in Czech)

Př́rCHYSTAL A (1998) Badenian potassium trachyandesites at the contact of the Bohemian Massif and West Carpathians. In: Ulrych J, CAJZ V, Adamovič J (eds) Magmatism and Rift Basin Evolution: International Geological Correlation Programme: Liblice, Czech Republic, September 7-11, 1998. Institute of Geology, Academy of Sciences of the Czech Republic, Prague, pp 85

PUTIRKA KD (2005) Igneous thermometers and barometers based on plagioclase + liquid equilibria: tests of some existing models and new calibrations. Amer Miner 90: 336-346

PutiRka KD (2008) Thermometers and barometers for volcanic systems. In. PUtiRKa KD, TePLEY III FJ (eds) Minerals, Inclusions, and Volcanic Processes. Mineralogical Society of America Reviews in Mineralogy and Geochemistry 69: 61-120

PUTIRKA KD (2016) Amphibole thermometers and barometers for igneous systems and some implications for eruption mechanisms of felsic magmas at arc volcanoes. Amer Miner 101: 841-858

RapPRich V, ShieldS S, Halodová P, LindLINe J, van WyK de Vries B, Petronis MS Valenta J (2017) Fingerprints 
of magma mingling processes within the Miocene Zebín tuff cone feeding system (Jičín Volcanic Field, Czech Republic). J Geosci 62: 215-229

Ridolfi F, Renzulli A (2012) Calcic amphiboles in calcalkaline and alkaline magmas: thermobarometric and chemometric empirical equations valid up to $1,130^{\circ} \mathrm{C}$ and 2.2 GPa. Contrib Mineral Petrol 163: 877-895

Ridolfi F, Puerini M, Renzulli A, Menna M, ToulkeriDIS T (2008) The magmatic feeding system of El Reventador volcano (Sub-Andean zone, Ecuador) constrained by texture, mineralogy and thermobarometry of the 2002 erupted products. J Volcanol Geotherm Res 176: 94-106

Ridolfi F, Renzulli A, Puerini M (2010) Stability and chemical equilibrium of amphibole in calc-alkaline magmas: an overview, new thermobarometric formulations and application to subduction related volcanoes. Contrib Mineral Petrol 160: 45-66

RoONEy TO (2010) Geochemical evidence of lithospheric thinning in the southern Main Ethiopian Rift. Lithos 117: 33-48

Rutherford MJ, Devine JD (2003) Magmatic conditions and magma ascent as indicated by hornblende phase equilibria and reactions in the 1995-2002 Soufrière Hills magma. J Petrol 44: 1433-1454

Salaün A, Villemant B, Gerard M, Komorowskij JC, Michel A (2011) Hydrothermal alteration in andesitic volcanoes: trace element redistribution in active and ancient hydrothermal systems of Guadeloupe (Lesser Antilles). J Geochem Explor 111: 59-83

Sato H, NaKada S, Fuji T, NaKamura M, Suzuki-Kamata K (1999) Groundmass pargasite in the 1991-1995 dacite of Unzen Volcano: phase stability experiments and volcanological implications. J Volcanol Geotherm Res 89: 197-212

Scaillet B, Evans BW (1999) The 15 June 1991 eruption of Mount Pinatubo, I, Phase equilibria and pre-eruption $\mathrm{P}-\mathrm{T}-\mathrm{fO}_{2}-\mathrm{H}_{2} \mathrm{O}$ conditions of the dacite magma. J Petrol 40: $381-411$

SEGHedi I, Downes H (2011) Geochemistry and tectonic development of Cenozoic magmatism in the Carpathian-Pannonian region. Gondwana Res 20: 655-672

Seghedi I, Balintoni I, SzaKács A (1998) Interplay of tectonics and Neogene postcollisional magmatism in the intracarpathian region. Lithos 45: 483-497

Seghedi I, Downes H, Szakács A, Mason PRD, Thirlwall MF, Roşu E, Pécskay Z, Márton E, Panaiotu C (2004) Neogene-Quaternary magmatism and geodynamics in the Carpathian-Pannonian region: a synthesis. Lithos 72: 117-146

Seghedi I, Downes H, Harangi S, Mason PRD, Pécskay Z (2005) Geochemical response of magmas to Neogene-
Quaternary continental collision in the Carpathian-Pannonian region. Tectonophysics 410: 485-499

Shane P, Smith VC (2013) Using amphibole crystals to reconstruct magma storage temperatures and pressures for the post-caldera collapse volcanism at Okataina Volcano. Lithos 156-159

SHRBENÝ O (1974) The petrochemical relation of the southMoravian neovolcanic rocks to the neighbouring volcanic area. Věst Ústř Úst Geol 49: 275-279

Singer BS, Dungan MA, Layne GD (1995) Textures and $\mathrm{Sr}, \mathrm{Ba}, \mathrm{Mg}, \mathrm{Fe}, \mathrm{K}$ and Ti compositional profiles in volcanic plagioclase: clues to the dynamics of calc-alkaline magma chamber. Amer Miner 80: 776-798

StimaC JA, PEARCE TH (1992) Textural evidence of maficfelsic magma interaction in dacite lavas, Clear Lake, California. Amer Miner 77: 795-809

Szabó C, Harangi S, Csontos L (1992) Review of Neogene and Quaternary volcanism of the Carpathian-Pannonian region. Tectonophysics 208: 243-256

TARi G, Dövényi P, Dunkl I, Horváth F, Lenkey L, SteFÁNescu M, SzAFIÁN P, TóTH T (1999) Lithospheric structure of the Pannonian Basin derived from seismic, gravity and geothermal data. In: DuRAND B, JOLIVET L, HorváTH F, SÉRANNE M (eds) The Mediterranean Basins: Tertiary Extension Within the Alpine Orogen. Geological Society of London Special Publications 156: 215-250

TAYLOR SR, MCLENNAN SM (1995) The geochemical evolution of the continental crust. Rev Geophys 33: 241-265

Tetsopgang S, Enami M, Nuonfang E (2011) Emplacement $\mathrm{P}-\mathrm{T}$ conditions of Pan-African biotite-amphibole granitoids in the Nkambe area, Cameroon. J Mineral Petrol Sci 106: 306-319

Tiepolo M, Tribuzio R, Langone A (2011) High-Mg andesite petrogenesis by amphibole crystallization and ultramafic crust assimilation: evidence from Adamello hornblendites (Central Alps, Italy). J Petrol 52: 1011-1045

Tracy RJ, Robinson P (1977) Zoned titanian augite in alkali olivine basalt from Tahiti and the nature of titanium substitution in augite. Amer Miner 62: 634-645

TsuchiYAma A (1985) Dissolution kinetics of plagioclase in melt of the system diopside-albite-anorthite, and origin of dusty plagioclase in andesite. Contrib Mineral Petrol 89: 1-16

Ulmanová J (2015) Formation Conditions of Selected Mineralizations from the Bučník Quarry near Komňa. Unpublished BSci Thesis, Palacký University, Olomouc, pp 1-39

Venezky DY, Rutherford MJ (1997) Preeruption conditions and timing of dacite-andesite magma mixing in the 2.2 ka eruption at Mount Rainier. J Geophys Res 102: 20069-20086

Whitney DL, Evans BW (2010) Abbreviations for names of rock-forming minerals. Amer Miner 95:185-187 